\title{
Model analyses of atmospheric mercury: present air quality and effects of transpacific transport on the United States
}

\author{
H. Lei ${ }^{1}$, X.-Z. Liang ${ }^{2}$, D. J. Wuebbles ${ }^{1}$, and Z. Tao ${ }^{3}$ \\ ${ }^{1}$ Department of Atmospheric Sciences, University of Illinois, Urbana, Illinois, USA \\ ${ }^{2}$ Department of Atmospheric and Oceanic Science, and Earth System Science Interdisciplinary Center, University of \\ Maryland, College Park, Maryland, USA \\ ${ }^{3}$ Universities Space Research Association/NASA Goddard Space Flight Center, Greenbelt, Maryland, USA
}

Correspondence to: D. J. Wuebbles (wuebbles@illinois.edu) and H. Lei (hang.lei@noaa.gov)

Received: 12 January 2013 - Published in Atmos. Chem. Phys. Discuss.: 15 April 2013

Revised: 29 July 2013 - Accepted: 9 October 2013 - Published: 7 November 2013

\begin{abstract}
Atmospheric mercury is a toxic air and water pollutant that is of significant concern because of its effects on human health and ecosystems. A mechanistic representation of the atmospheric mercury cycle is developed for the state-of-the-art global climate-chemistry model, CAMChem (Community Atmospheric Model with Chemistry). The model simulates the emission, transport, transformation and deposition of atmospheric mercury $(\mathrm{Hg})$ in three forms: elemental mercury $(\mathrm{Hg}(0))$, reactive mercury $(\mathrm{Hg}(\mathrm{II}))$, and particulate mercury (PHg). Emissions of mercury include those from human, land, ocean, biomass burning and volcano related sources. Land emissions are calculated based on surface solar radiation flux and skin temperature. A simplified air-sea mercury exchange scheme is used to calculate emissions from the oceans. The chemistry mechanism includes the oxidation of $\mathrm{Hg}(0)$ in gaseous phase by ozone with temperature dependence, $\mathrm{OH}, \mathrm{H}_{2} \mathrm{O}_{2}$ and chlorine. Aqueous chemistry includes both oxidation and reduction of $\mathrm{Hg}(0)$. Transport and deposition of mercury species are calculated through adapting the original formulations in CAM-Chem. The CAM-Chem model with mercury is driven by present meteorology to simulate the present mercury air quality during the 1999-2001 period. The resulting surface concentrations of total gaseous mercury (TGM) are then compared with the observations from worldwide sites. Simulated wet depositions of mercury over the continental United States are compared to the observations from 26 Mercury Deposition Network stations to test the wet deposition simulations. The evaluations of gaseous concentrations and wet deposition confirm a strong capability for the CAM-Chem mercury
\end{abstract}

mechanism to simulate the atmospheric mercury cycle. The general reproduction of global TGM concentrations and the overestimation on South Africa indicate that model simulations of TGM are seriously affected by emissions. The comparison to wet deposition indicates that wet deposition patterns of mercury are more affected by the spatial variability of precipitation. The sensitivity experiments show that $22 \%$ of total mercury deposition and $25 \%$ of TGM concentrations in the United States result from domestic anthropogenic sources, but only $9 \%$ of total mercury deposition and $7 \%$ of TGM concentrations are contributed by transpacific transport. However, the contributions of domestic and transpacific sources on the western United States levels of mercury are of comparable magnitude.

\section{Introduction}

Mercury is a toxic pollutant, having harmful effects on human health and ecosystems. The United States and many other countries have listed mercury as a major air pollutant that requires regulatory control (e.g., US Clean Air Act, 1990; EMEP, 2005). Mercury is emitted into the air in forms of elemental mercury $(\mathrm{Hg}(0))$, reactive gaseous mercury (RGM, gaseous $\mathrm{Hg}$ (II) compounds) and particulate mercury $(\mathrm{PHg})$. Elemental mercury accounts for more than $90 \%$ of total atmospheric mercury (Schroeder and Munthe, 1998). Its atmospheric lifetime (several months) is long enough for global-scale transport. As such, mercury is a global air pollutant and it is difficult to attribute the relative importance of its 
local and/or remote emissions sources. Several atmospheric models such as GEOS-Chem, CMAQ, HYPLIT, GRAHM, ECHMERIT, CTM-Hg, and MSCE-Hg have been developed and achieved successful simulations of tropospheric mercury against available observations (Bullock and Brehme, 2002; Cohen et al., 2004; Selin et al., 2007, 2008; Bullock et al., 2008, 2009; Pirrone and Keating, 2010; AMAP/UNEP, 2008, 2013). However, along with the remaining issues on emission estimates (Lin et al., 1999, 2006), recently there have been arguments raised regarding the chemical transformation of atmospheric mercury (Calvert and Lindberg, 2005; Holmes et al., 2010; Lyman and Jaffe, 2012; Rutter et al., 2012). Therefore, it is necessary to develop mercury models that incorporate the relevant emission, transport, and deposition processes as well as represent and test different mercury mechanisms.

The main issue about atmospheric mercury chemistry relates to the oxidation mechanism (Hynes et al., 2009). Previous atmospheric mercury models were mainly based on the oxidation of elemental mercury by ozone $\left(\mathrm{O}_{3}\right)$ and hydroxyl (OH) (Bullock and Brehme, 2002; Lin et al., 2006; Selin et al., 2007, 2008). These models have achieved successful global and regional validations against the near-surface observations but have problems in reproducing the concentrations of mercury species in the upper troposphere and Antarctic summer (Sprovieri et al., 2002; Temme et al., 2003; Lin et al., 2006). Based on chemical kinetics, Calvert and Lindberg (2005) pointed out that the mercury oxidation from this mechanism in the real atmosphere might be much slower than the reported laboratory results (Hall, 1995; Sommar et al., 2001; Pal and Ariya, 2004). However, aircraft-based measurements in the upper troposphere and lower stratosphere show that concentrations of total mercury and reactive mercury rapidly respond to the variation in ozone concentrations, indicating the possibility of the $\mathrm{O}_{3}-\mathrm{OH}$ oxidation mechanism dominating the transformation of atmospheric mercury (Lyman and Jaffe, 2011). Further experiments on rate measurements also strongly support the oxidation mechanism by ozone in the presence of secondary organic aerosols and directly refute the previous comments on the laboratory results (Rutter et al., 2012). While the role for $\mathrm{OH}$ in the oxidation of mercury still needs further study, the chemistry for bromine $(\mathrm{Br})$ oxidation of mercury has been developed based on theoretical kinetic calculations (Goodsite et al., 2004; Holmes et al., 2006). Holmes et al. (2010) evaluated the bromine oxidation mechanism in the GEOS-Chem $\mathrm{Hg}$ model. As reviewed by Subir et al. (2011), our current status of knowledge on these mercury reactions reflects a lack of sufficient understanding of such mechanisms. Additional measurements and modeling studies are needed to achieve a better understanding of the atmospheric mercury life cycle.

Another major challenge for modeling mercury is to obtain a well-characterized evaluation of global emissions. The current emission inventory data sets are known to contain substantial uncertainties (Pacyna et al., 2005; Street et al., 2009).
Anthropogenic sources make-up between a quarter and one third of the current mercury emissions (Mason and Sheu, 2002; Pacyna et al., 2005; Selin et al., 2007; Soerensen et al., 2010; Holmes et al.,2010; Mason et al., 2012). These include coal-fired power production, metal smelting, and waste incineration (Mason and Sheu, 2002; Pacyna et al., 2005; Streets et al., 2005). All of these sources are highly variable and total source rates are not well known, causing large uncertainties in estimating their emission inventories. Natural sources include fluxes from water bodies, soil, terrestrial vegetation, volcanic eruptions, and biomass burning. The difficulty in estimating natural emissions is to represent the surface fluxes in response to meteorological and physical conditions (Poissant and Casimir, 1998; Zhang et al., 2001). The accurate estimate of the spatial and temporal distributions of emissions from major sources is the foundation for a successful simulation of atmospheric mercury.

In addition to the major problems above, a complete atmospheric mercury model also requires consideration of heterogeneous chemistry, transport processes, wet and dry deposition processes. Recent intercomparison studies have shown that large differences in modeled results over North America are caused mainly by inconsistent treatments of the chemical and physical processes affecting $\mathrm{Hg}$ transport and transformation (Bullock et al., 2008, 2009). Starting from a simple atmospheric model, the NCAR Community Atmospheric Model with Chemistry (CAM-Chem) has been developed with advanced representations of dynamical, physical, and chemical processes; it serves as a powerful tool for investigating the global atmospheric environment and climate interactions (Lamarque et al., 2005, 2012; Heald et al., 2008; Pfister et al., 2008). The original CAM-Chem model does not include the chemical and physical processes necessary to simulating the atmospheric and surface mercury distributions, but it provides a platform to build a reliable atmospheric mercury model.

This study is aimed at developing and incorporating into the CAM-Chem model a mercury module based on the latest available numerical representations of all processes essential to the mercury life cycle (e.g., Subir et al., 2011; Rutter et al., 2012). The basic chemical mechanism is based on the $\mathrm{O}_{3}-\mathrm{OH}$ oxidation, but we also test the effects of $\mathrm{Br}$ oxidation on surface mercury concentrations. We account for spatial and temporal variability of all three types of mercury $(\mathrm{Hg}(0), \mathrm{Hg}(\mathrm{II}), \mathrm{PHg})$ emitted and re-emitted from various sources over both land and oceans by modifying and incorporating two dynamic parameterization models (Liss and Slater, 1974; Zhang et al., 2001; Wängberg et al., 2001). The expanded CAM-Chem with the mercury mechanism simulates the atmospheric pathways of all forms of mercury from their source emissions to eventual deposition back to land and water surfaces through both wet and dry atmospheric processes across a wide range of spatial and temporal scales. The viability of the model, hereafter called CAM-Chem $/ \mathrm{Hg}$, is evaluated based on multi-year 
simulations driven by representative meteorological conditions from the global observational reanalysis. The results are compared against the best-available observations for surface mercury concentration and wet deposition, including data from the National Atmospheric Deposition Program (NADP) (Lindberg and Vermette, 1995), major networks in Europe (EMEP) and Canada (CAMNet), as well others from the published literature (Friedli et al., 2004; Kock et al., 2005). The CAM-Chem/ $\mathrm{Hg}$ model is then used to evaluate the contributions of transpacific transport and domestic anthropogenic emissions to US mercury concentrations.

\section{Model formulation}

\subsection{The CAM-Chem model}

The CAM-Chem model used in this study is an integral part of the Community Climate System Model version 3 (CCSM3) that includes fully coupled atmospheric, land, ocean, and sea ice components (Collins et al., 2006; Lamarque et al., 2008). The gas-aerosol phase chemistry is based on the MOZART (Model of Ozone and Related Chemical Tracers) chemistry-transport model (Horowitz et al., 2003; Tie et al., 2001, 2005). It has been rigorously evaluated and widely used in the recent chemistry-climate studies (Heald et al., 2008; Lamarque et al., 2005, 2008; Murazaki and Hess, 2006; Emmons et al., 2010; Lei et al., 2012, 2013). The chemical module includes 85 gas-phase species, 12 bulk aerosol compounds, 39 photolysis and 157 gas-phase reactions. The aerosol module includes sulfate, black carbon, primary organic, secondary organic, ammonium nitrate, and sea salt (Lamarque et al., 2005, 2008, 2012). Wet deposition is modeled by the formulation of Neu and Prather (2011). See Lamarque et al. $(2008,2012)$ for a more extensive description of the model.

This study adopts anthropogenic emissions mostly from the POET (Precursors of Ozone and their Effects in the Troposphere) database for 2000 (Granier et al., 2005; Olivier et al., 2003), including those of fossil fuel and biofuel combustion based on the EDGAR-3 inventory (Olivier et al., 2001). Biogenic emissions of isoprene and monoterpenes, and nitric oxide (NO) emissions from soil, are calculated online using the Model of Emissions of Gases and Aerosols from Nature (MEGAN) (Guenther et al., 2006) as implemented by Pfister et al. (2008). Biomass burning emissions are taken from the Global Fire Emissions Database version 2 (GFED-v2), with monthly averaged data available for 1997-2007 (van der Werf et al., 2006).

A simulation for the years 1998-2001 was carried out with CAM-Chem for evaluations relative to observations. The simulation is driven by meteorological fields from the NCEP/DOE AMIP II reanalysis (Kanamitsu et al., 2002), including winds, mixed-layer depths, temperature, precipitation, and convective mass fluxes. These data are available at a $6 \mathrm{~h}$ interval and a grid spacing of $1.9^{\circ} \times 2.5^{\circ}$ with 26 hybrid sigma-pressure levels. The initial year, 1998 , is considered as a spin-up. The subsequent analyses focus mainly on the statistics for year 2000 and the average of 1999-2001 relative to the respective observations.

\subsection{Mercury chemistry}

The treatment of mercury chemistry used here considers major pathways in both gas and aqueous phases. The gas-phase reactions include the oxidation of $\mathrm{Hg}(0)$ to $\mathrm{Hg}$ (II) by $\mathrm{OH}$, ozone, and chlorine (Hall, 1995; Sommar et al., 2001; Calhoun and Prestbo, 2001; Pal and Ariya, 2004; Subir et al., 2011), which represents the core mechanism for the CAM$\mathrm{Chem} / \mathrm{Hg}$ model. The evaluations of simulated concentrations of ozone, $\mathrm{OH}$, sulfite, and chlorine by the CAM-Chem or chemistry-transport model with the same chemical mechanism (e.g., MOZART) have been carried out against a verity of measurements (Emmons et al., 2010; Lei et al., 2012, 2013; Saiz-Lopéz et al., 2012; Lamarque et al., 2012). The bromine oxidation reactions are not included in the core mercury module due to incomplete knowledge of the bromine chemistry and emissions in CAM-Chem. However, a sensitivity experiment does consider this by using the global bromine field from GEOS-Chem to test possible effects on the global mercury distribution. Table 1 lists the detailed $\mathrm{Hg}$ chemical reactions and their rate constants (Gbor et al., 2006; Subir et al., 2011; Rutter et al., 2012). Hg(II) gasparticle partitioning is also shown in Table 1 . $\mathrm{Hg}$ (II) phase partitioning affects both wet and dry deposition. The partitioning of $\mathrm{Hg}(\mathrm{II})$ is assumed to be divided equally between the gas and particle phases for oxidation by ozone, $\mathrm{OH}$, and $\mathrm{H}_{2} \mathrm{O}_{2}$. The oxidation products by chlorine and $\mathrm{Br}$ are all reactive mercury. For the main chemical mechanism, the gaseous reactions produce RGM that is soluble in water (with a Henry's law constant of $1.4 \times 10^{6} \mathrm{M} \mathrm{atm}^{-1}$ ), and thus dissolves to $\mathrm{Hg}^{2+}$ in aqueous aerosols and clouds (Pleijel and Munthe, 1995; Schroeder and Munthe, 1998). In the aqueous phase, the reduction of $\mathrm{Hg}^{2+}$ into $\mathrm{Hg}^{0}$ has been shown to be important in laboratory studies (Pehkonen and Lin, 1998; Lin and Tao, 2003). The transformation from $\mathrm{Hg}^{2+}$ to $\mathrm{Hg}^{0}$ can be achieved mainly through photochemical reactions or reactions with $\mathrm{SO}_{3}^{2-}$, while the occurrence of reduction reactions with $\mathrm{HO}_{2}$ in the atmosphere is doubted (Gardfeldt and Jonsson, 2003; Lin et al., 2007). Due to the relatively low solubility of $\mathrm{Hg}^{0}$ (with a Henry's law constant of $1.1 \times 10^{-1} \mathrm{M} \mathrm{atm}^{-1}$ ), the oxidation of $\mathrm{Hg}^{0}$ based on the dissolution of gaseous elemental mercury may not be significant. However, when considering the reduction of $\mathrm{Hg}^{2+}$, the aqueous mechanisms included in Table 1 can be important for the mercury chemical equilibrium. 
Table 1. Reactions rate and $\mathrm{Hg}(\mathrm{II})$ gas-particle partitioning in the CAM-Chem/Hg model.

\begin{tabular}{|c|c|c|}
\hline Reactions & Rate constant & Reference \\
\hline Gaseous Reactions & Unit: $\mathrm{cm}^{3}$ molec ${ }^{-1} \mathrm{~s}^{-1}$ & \\
\hline $\mathrm{Hg}_{(\mathrm{g})}^{0}+\mathrm{O}_{3(\mathrm{~g})} \rightarrow 0.5 \mathrm{PHg}+0.5 \mathrm{RGM}^{*}$ & $2.11 \times 10^{-18} \exp \left(-1256.5 T^{-1}\right)$ & Gbor et al. (2006) Rutter et al. (2012) \\
\hline $\mathrm{Hg}_{(\mathrm{g})}^{\mathrm{O}}+\mathrm{H}_{2} \mathrm{O}_{2(\mathrm{~g})} \rightarrow 0.5 \mathrm{PHg}+0.5 \mathrm{RGM}^{*}$ & $8.5 \times 10^{-19}$ & USEPA (1997) \\
\hline $\mathrm{Hg}_{(\mathrm{g})}^{0}+\mathrm{Cl}_{2(\mathrm{~g})} \rightarrow \mathrm{RGM}$ & $2.6 \times 10^{-18}$ & Gbor et al. (2006) \\
\hline $\mathrm{Hg}_{(\mathrm{g})}^{0}+\mathrm{OH}_{(\mathrm{g})} \rightarrow 0.5 \mathrm{PHg}+0.5 \mathrm{RGM}^{*}$ & $9.0 \times 10^{-14}$ & Subir et al. (2011) \\
\hline \multicolumn{3}{|l|}{ Additional Bromine reactions } \\
\hline $\mathrm{Hg}_{(\mathrm{g})}^{0}+\mathrm{Br}_{(\mathrm{g})} \rightarrow \mathrm{HgBr}_{(\mathrm{g})}$ & $1.5 \times 10^{-32}(T / 298)^{-1.86}$ & Donohoue et al. (2006) \\
\hline $\mathrm{HgBr}_{(\mathrm{g})}+\mathrm{Br}_{(\mathrm{g})} \rightarrow \mathrm{RGM}$ & $2.5 \times 10^{-10}(T / 298)^{-0.57}$ & Goodsite et al. (2004) \\
\hline $\mathrm{HgBr}_{(\mathrm{g})}+\mathrm{OH}_{(\mathrm{g})} \rightarrow 0.5 \mathrm{PHg}+0.5 \mathrm{RGM}^{*}$ & $2.5 \times 10^{-10}(T / 298)^{-0.57}$ & Goodsite et al. (2004) \\
\hline $\mathrm{HgBr}_{(\mathrm{g})} \rightarrow \mathrm{Hg}_{(\mathrm{g})}^{0}+\mathrm{Br}_{(\mathrm{g})}$ & $3.9 \times 10^{9} \exp \left(-8357 T^{-1}\right)(T / 298)^{-0.57}$ & Holmes et al. (2010) \\
\hline $\mathrm{HgBr}_{(\mathrm{g})}+\mathrm{Br}_{(\mathrm{g})} \rightarrow \mathrm{Hg}_{(\mathrm{g})}^{0}+\mathrm{Br}_{(\mathrm{g})}$ & $3.9 \times 10^{-11}$ & Balabanov et al. (2005) \\
\hline Aqueous Reactions & Unit: $\mathrm{m}^{-1} \mathrm{~s}^{-1}$ & \\
\hline $\mathrm{Hg}_{(\mathrm{aq})}^{0}+\mathrm{O}_{3(\mathrm{aq})} \rightarrow \mathrm{Hg}_{(\mathrm{aq})}^{2+}+$ products & $4.7 \times 10^{7}$ & Munthe (1992) \\
\hline $\mathrm{HgSO} 3 \rightarrow \mathrm{Hg}_{(\mathrm{aq})}^{0}+$ products & $T \exp \left(31.971-12595 T^{-1}\right)$ & Van Loon et al. (2000) \\
\hline $\mathrm{Hg}_{(\mathrm{aq})}^{2+}+\mathrm{HO}_{2(\mathrm{aq})} \rightarrow \mathrm{Hg}_{(\mathrm{aq})}^{0}+$ products & $1.1 \times 10^{4}$ & Pehkonen and Lin (1998) \\
\hline $\mathrm{Hg}(\mathrm{OH})_{2(\mathrm{aq})}+\mathrm{hv} \rightarrow \mathrm{Hg}_{(\mathrm{aq})}^{0}+$ products & $6.0 \times 10^{-7}$ & Xiao et al. (1994) \\
\hline $\mathrm{Hg}_{(\mathrm{aq})}^{0}+\mathrm{OH}_{(\mathrm{aq})} \rightarrow \mathrm{Hg}_{(\mathrm{aq})}^{+}+$products & $2.4 \times 10^{10}$ & Lin and Pehkonen (1997) \\
\hline $\mathrm{Hg}_{(\mathrm{aq})}^{+}+\mathrm{OH}_{(\mathrm{aq})} \rightarrow \mathrm{Hg}_{(\mathrm{aq})}^{2+}+$ products & 0.1 & Gardfeldt et al. (2001) \\
\hline $\mathrm{Hg}_{(\mathrm{aq})}^{0}+\mathrm{HOCl}_{(\mathrm{aq})} \rightarrow \mathrm{Hg}_{(\mathrm{aq})}^{2+}+$ products & $2.09 \times 10^{6}$ & Lin and Pehkonen (1998) \\
\hline $\mathrm{Hg}_{(\mathrm{aq})}^{0}+\mathrm{OCl}_{(\mathrm{aq})}^{-} \rightarrow \mathrm{Hg}_{(\mathrm{aq})}^{2+}+$ products & $1.99 \times 10^{6}$ & Lin and Pehkonen (1998) \\
\hline \multicolumn{3}{|l|}{ Additional Bromine reactions } \\
\hline $\mathrm{Hg}_{(\mathrm{aq})}^{+}+\mathrm{Br}_{2(\mathrm{aq})} \rightarrow \mathrm{Hg}_{(\mathrm{aq})}^{2+}+$ products & 0.2 & Wang and Pehkonen (2004) \\
\hline $\mathrm{Hg}_{(\mathrm{aq})}^{+}+\mathrm{HOBr}_{(\mathrm{aq})} \rightarrow \mathrm{Hg}_{(\mathrm{aq})}^{2+}+$ products & 0.28 & Wang and Pehkonen (2004) \\
\hline $\mathrm{Hg}_{(\mathrm{aq})}^{+}+\mathrm{OBr}_{(\mathrm{aq})}^{-} \rightarrow \mathrm{Hg}_{(\mathrm{aq})}^{2+}+$ products & 0.27 & Wang and Pehkonen (2004) \\
\hline
\end{tabular}

* The partitioning is expected to depend on temperature, aerosol load, and aerosol composition (Lin et al., 2006; Rutter and Schauer, 2007). Future work will link $\mathrm{Hg}$ (II) partitioning to environment conditions, while here we assume 50/50 partitioning of $\mathrm{Hg}$ (II) as widely used in recent studies (Holmes et al., 2010).

\subsection{Mercury deposition}

The treatment for wet deposition of $\mathrm{Hg}(0), \mathrm{RGM}$ and $\mathrm{PHg}$ follows that used for all other aqueously sensitive pollutants resolved in the standard CAM-Chem. It is based on the formulation of Brasseur et al. (1998), considering the solution scavenging and incorporating the main parameterization introduced by Giorgi and Chameides (1985). The wet deposition treatment includes rainout and washout from stratiform and convective precipitation, and scavenging in convective updrafts (Liu et al., 2001). In addition, the uptake by the marine boundary layer is also regarded as a major deposition process for Hg (Hedgecock et al., 2001; Selin et al., 2007), and is considered in the calculation of the mercury air-sea exchange process. The aqueous concentration of $\mathrm{Hg}^{0}$ is low relative to the total dissolved $\mathrm{Hg}^{2+}$, and thus its wet deposition is minor compared to that of $\mathrm{Hg}(\mathrm{II})$ and $\mathrm{PHg}$.
The treatment for dry deposition of mercury species also follows that for other chemicals in the standard CAM-Chem. Some previous studies neglected dry deposition of $\mathrm{Hg}(0)$ due to the rapid reemission from the ground (Bullock et al., 2002; Selin et al., 2008). Recent studies have shown that 5-40\% of newly deposited mercury is rapidly reemitted back to the atmosphere over non-snow land surfaces (Hintelmann et al., 2002; Amyot et al., 2004), and up to $60 \%$ over snow surfaces (Lalonde et al., 2001; Ferrari et al., 2005). Suggested by previous isotopic field studies and empirical estimates (Amyot et al., 2004; Graydon et al., 2006; Selin et al., 2008), the rapid reemission of mercury in the CAM-Chem has been considered in the land emission inventory by returning $20 \%$ of total deposited $\mathrm{Hg}(\mathrm{II})$ as $\mathrm{Hg}(0)$. Therefore, we determine the dry deposition velocities of $\operatorname{Hg}(0)$ online in the model, based on the resistance-based parameterization of Wesely (Walmsley and Wesely, 1996; Wesely and Hicks, 2000). Dry deposition 
of $\mathrm{Hg}(\mathrm{II})$ and $\mathrm{PHg}$ is simulated with the scheme based on local surface type and turbulence (Wang et al., 1998; Wesely, 1989).

\subsection{Mercury emissions}

Here we adopt the anthropogenic mercury emissions in 2000 from the Global Mercury Emission Inventory (Pacyna et al., 2006) as the present emission from anthropogenic sources. These sources include major industrial emitters from coalfired power production, mining, metal smelting, and waste incineration (Streets et al., 2005; Mason and Sheu, 2002).

Land sources include emissions from soil and vegetation, plus rapid reemissions of deposited mercury. Soil and vegetation contribute about 500-1800 $\mathrm{Mg} \mathrm{yr}^{-1}$ (Lindqvist, 1991; Seigneur et al., 2001; Selin et al., 2007), while the reemissions range is $260-1500 \mathrm{Mg} \mathrm{yr}^{-1}$ (Selin et al., 2008; SmithDowney et al., 2010), resulting in a total estimate of 1100 $3000 \mathrm{Mg} \mathrm{yr}^{-1}$. Land emissions depend on both soil temperature (Lindberg et al., 1995; Poissant and Casimir, 1998) and surface solar radiation (Carpi and Lindberg, 1998; Zhang et al., 2001; Gustin et al., 2002). Land mercury emissions are calculated using local temperature, solar flux, and estimated source distribution. By using the GEOS-Chem soil mercury pool, the average emission flux $\left(F_{1}\right)$ for the present is distributed based on soil mercury storage (Selin et al., 2008; Smith-Downey, et al., 2010). It is then adjusted using the relationship suggested by Zhang et al. (2001) and Poissant and Casimir (1998):

$F_{2}=F_{1} \exp \left[-1.1 \times 10^{4}\left(1 / T_{\mathrm{S}}-1 / T_{0}\right)\right] \exp \left[1.1 \times 10^{3}\left(R_{\mathrm{S}}-R_{0}\right)\right]$

where $F_{2}$ is the calculated land emission flux. $R_{\mathrm{S}}$ is the surface solar radiation flux and $T_{\mathrm{S}}$ is the local surface skin temperature. The reference value is $340 \mathrm{~W} \mathrm{~m}^{-2}$ for $R_{0}$ and $288 \mathrm{~K}$ for $T_{0}$. The parameterization is subject to calibration using the multi-year average (1995-2005 monthly mean) $R_{\mathrm{s}}$ and $T_{\mathrm{S}}$ distributions from the NECP reanalysis. The $F_{1}$ has been adjusted to constrain the global annual total emission of $2900 \mathrm{Mg} \mathrm{yr}^{-1}$ estimated for 2000 (Smith-Downey et al., 2010).

Ocean emissions are determined by a simplified air-sea exchange scheme that has been tested through field campaigns for good agreement with observations (Liss and Slater, 1974; Wängberg et al., 2001). We estimate monthly mean mercury flux at ocean surface through the following scheme that also removes the dependence on the mercury storage in deep oceans:

$F=K_{\mathrm{w}}\left(C_{\mathrm{w}}-C_{\mathrm{a}} / H^{\prime}\right)$,

where $F$ is the ocean emission flux of mercury, $H^{\prime}=[\mathrm{Hg}]_{(\mathrm{g})} /[\mathrm{Hg}]_{(\mathrm{aq})}$ is the dimensionless Henry's law constant calculated at water temperatures $\left(T_{\mathrm{w}}\right)$ (Clever et al., 1985), $K_{\mathrm{w}}$ is the gas transfer velocity of a species in the water-air interface based on the empirical relation of
Wanninkhof (1992), and $C_{\mathrm{w}}$ and $C_{\mathrm{a}}$ are respectively the $\operatorname{Hg}(0)$ concentration in the mixed-layer ocean $\left(\mathrm{pg} \mathrm{L}^{-1}\right)$ and in the surface atmosphere $\left(\mathrm{ng} \mathrm{m}^{-3}\right) . C_{\mathrm{w}}$ is simplified by using the monthly mean concentration data (Soerensen et al., 2010), which has considered the contribution from deposition, while $C_{\mathrm{a}}$ is determined by the atmospheric model.

Biomass burning emissions are specified as monthly means from the IPCC estimate of biomass burned and the IMAGE projection of managed forests for a typical year. The approach and emission factors as a function of vegetation types are adopted from Streets et al. (2009).

Volcanic emissions of mercury are based on those of sulfur in the GEIA inventory. The method uses a typical ratio of $\mathrm{Hg}$ relative to $\mathrm{SO}_{2}$ volcanic emissions to estimate mercury emissions. A similar method has been used in the previous studies (Ferrara et al., 2000; Nriagu et al., 2003; Pyle and Mather, 2003). Here we adopt a $\mathrm{Hg} / \mathrm{SO}_{2}$ ratio of $1.5 \times 10^{-6}$ for all volcanic eruptions (Aiuppa et al., 2007; Witt et al., 2008).

\subsection{Global budget}

Figure 1 summarizes the partition of global mercury emissions in 2000 among different sources. It shows that the oceans are the largest contributor, followed by natural land emissions and the human-related emissions. However, the oceanic flux per unit area is small as the total emissions are distributed over $72 \%$ the Earth's surface. In contrast, the average emission flux over land is 3.5 times larger than the flux over ocean, when counting the natural, anthropogenic, and biomass burning emissions together.

Our estimate of global total emissions from all sources is about $9680 \mathrm{Mg} \mathrm{yr}^{-1}$. This falls in the middle between the values of $6600 \mathrm{Mg} \mathrm{yr}^{-1}$ in the early estimate (Mason and Sheu, 2002) and $11200 \mathrm{Mg} \mathrm{yr}^{-1}$ used in the GEOS-Chem model (Selin et al., 2007, 2008). However, our estimate for the ocean emissions is notably larger than the previously published values ( 3400 versus $2600 \pm 300 \mathrm{Mg} \mathrm{yr}^{-1}$ ). This reflects our inclusion of emissions from the mixed-layer ocean storage and deposited mercury. Some other works also estimate the natural sources account for $5207 \mathrm{Mg} \mathrm{yr}^{-1}$ and anthropogenic sources for nearly $2320 \mathrm{Mg} \mathrm{yr}^{-1}$ (Mason, 2009; Pirrone et al., 2010), which overall is smaller than the emission data set used in this study. Mason (2009) estimate a volcano emission of $90 \mathrm{Mg} \mathrm{yr}^{-1}$ which is lower than our estimate (Mason, 2009). This comparison indicates large uncertainty among various global mercury emission inventories and the need to further assess the emission impact on model performance.

Dry and wet depositions of mercury are calculated separately in CAM-Chem $/ \mathrm{Hg}$, in contrast to the net removal rate considered in some studies (Bullock et al., 2002). On Earth's surface, total estimated deposition is around $8800 \mathrm{Mg} \mathrm{yr}^{-1}$, from which dry deposition accounts for $70 \%$. About $55 \%$ 


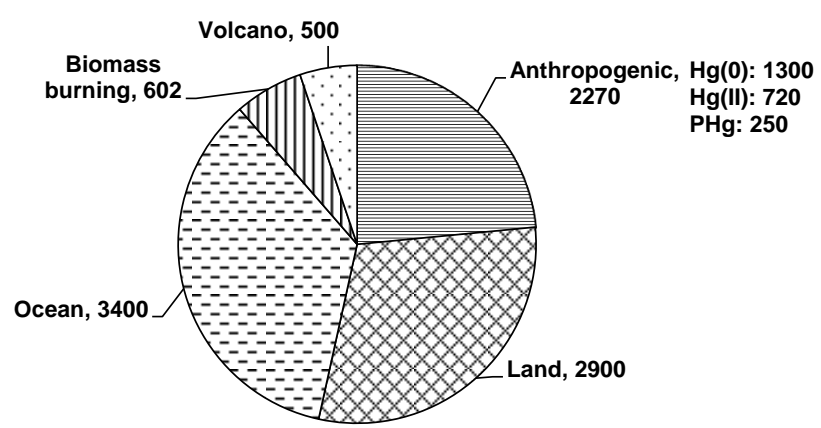

Fig. 1. Estimated global total mercury emissions $\left(\mathrm{Mg} \mathrm{yr}^{-1}\right)$ from different sources in 2000.

of total deposition occurs over the ocean and $45 \%$ over land. Over land, total deposition is $1800 \mathrm{Mg} \mathrm{yr}^{-1}$ for $\mathrm{Hg}$ (II), $1600 \mathrm{Mg} \mathrm{yr}^{-1}$ for $\mathrm{Hg}(0)$, and $600 \mathrm{Mg} \mathrm{yr}^{-1}$ for $\mathrm{PHg}$. The oceans are a net sink for atmospheric mercury, taking up approximately $2000 \mathrm{Mg} \mathrm{yr}^{-1}$, balancing a portion of the human-related and volcanic sources.

The CAM-Chem $/ \mathrm{Hg}$ model calculates a total mercury lifetime of $0.69 \mathrm{yr}$ in the atmosphere against deposition, as deposition is the only sink for total mercury in the model. Our derived lifetime of mercury agrees well with the estimated lifetime of $0.5-0.79 \mathrm{yr}$ determined in the GEOS-Chem model studies (Selin et al., 2007, 2008). Previous studies had estimated the lifetime at 1.0-1.7 yr (Bergan et al., 1999; Shia et al., 1999; Seigneur et al., 2001; Lamborg et al., 2002a). The shorter lifetime in the more recent studies may result from the modeling approaches where the processes of deposition and reemission are treated separately.

\section{Global mercury distribution}

\subsection{CAM-Chem $/ \mathrm{Hg}$ results}

Figure 2 shows the annual mean surface air concentrations of total gaseous mercury (TGM) averaged over the 1999-2001 time period as simulated by the CAM-Chem/Hg model using the present emission. The TGM is taken as the sum of gaseous $\mathrm{Hg}(0)$ and gaseous $\mathrm{Hg}(\mathrm{II})$. The major characteristic is that the mercury concentrations are greatest over land and coastal regions. The most-polluted area occurs in Asia, where strong surface TGM concentrations are derived along the continent boundaries. In particular, the concentrations across the Middle East, India, China, and Japan are above $3 \mathrm{ng} \mathrm{m}^{-3}$. The second most-polluted area is southern Africa, where high mercury emissions result from the intensive development of mercury-related industries, especially mining. Mining in Australia also results in heavy mercury deposition along the southeast coast. These areas of heavy mercury pollution are identified with high human-related emissions over land (Nelson, 2007). It is noted that high TGM concentra-

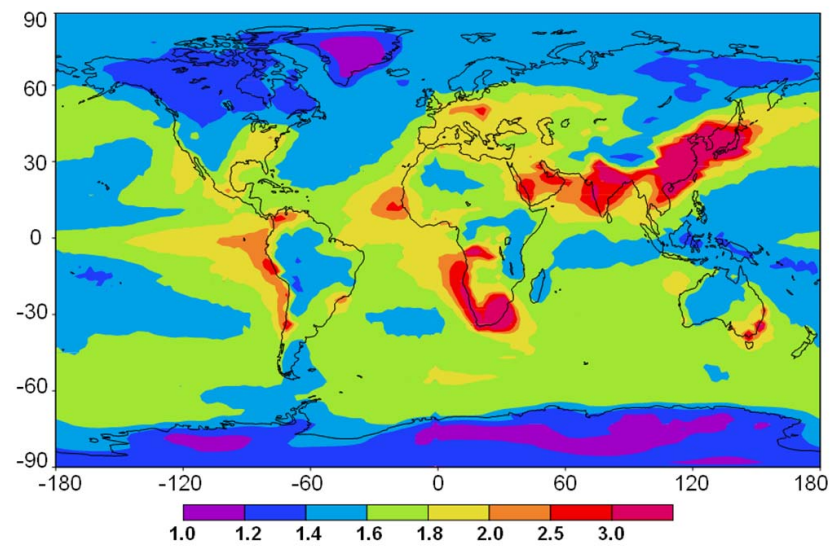

Fig. 2. Annual mean surface TGM concentrations $\left(\mathrm{ng} \mathrm{m}^{-3}\right)$ averaged in 1999-2001 derived by the CAM-Chem/Hg model.

tions are given by the model over upwelling regions along the west coasts of South America and Africa. This may be associated with the sensitivity and uncertainty in the ocean emission scheme used in this study. The emissions of $\mathrm{Hg}$ in upwelling regions usually contain more contributions from deep ocean storage of mercury. In response to the positive temperature anomaly in surface air, the scheme tends to predict a high emission. In contrast, the Antarctic pollution is low because of scarce human-related emissions. The high concentrations over the eastern coast of the South Atlantic are likely caused by transport of inland pollutants from South Africa under the prevailing easterly to northeasterly winds near the surface.

The derived CAM-Chem $/ \mathrm{Hg}$ model results share a general similarity with previous modeling studies. For example, the interhemispheric total integrated concentration in the Northern Hemisphere relative to that in the Southern Hemisphere, the TGM concentration ratios, for surface air were estimated to range between 1.2 and 1.8 (Lamborg et al., 2002b), without considering the heavily polluted East Asia. The CAM$\mathrm{Chem} / \mathrm{Hg}$ model derived value is 1.37 . The spatial pattern of TGM in our study also compares well with that from the GEOS-Chem model over the globe (Selin et al., 2007, 2008). In particular, the concentrations over land are very close between the GEOS-Chem and CAM-Chem/Hg models, while their differences (around $0.2 \mathrm{ng} \mathrm{m}^{-3}$ ) over oceans are largest in the Arctic. This disagreement may partially result from the use of different driving meteorological conditions that are important to mercury reactions and transport.

Table 2 compares the modeled 1999-2001 mean surface TGM concentrations with measurements at 21 land sites worldwide with varying periods (time average) between 1995 and 2007 (Selin et al., 2007). The geographic distribution of sites has good spatial representativeness of the global surface. The comparison shows that the model captures the general spatial pattern of global mercury air pollution. The TGM concentrations match the range of observations at 16 
Table 2. CAM-Chem/Hg simulated 1999-2001 annual mean total mercury concentrations compared with measurements with varying periods at available land sites worldwide.

\begin{tabular}{|c|c|c|c|c|}
\hline \multicolumn{4}{|c|}{ Observations } & \multirow[b]{2}{*}{ CAM-Chem/Hg $\left(\mathrm{ng} \mathrm{m}^{-3}\right)$} \\
\hline Site & Period & Reference* & Concentration $\left(\mathrm{ng} \mathrm{m}^{-3}\right)$ & \\
\hline Alert, Canada $\left(82^{\circ} \mathrm{N}, 62^{\circ} \mathrm{W}\right)$ & 1995-2002 & 1 & 1.55 & 1.43 \\
\hline Esther, Canada $\left(52^{\circ} \mathrm{N}, 110^{\circ} \mathrm{W}\right)$ & 1997-1999 & 4 & 1.69 & 1.15 \\
\hline Zeppelin, Norway $\left(79^{\circ} \mathrm{N}, 12^{\circ} \mathrm{E}\right)$ & 2000-2004 & 2 & 1.55 & 1.51 \\
\hline Pallas, Finland $\left(67^{\circ} \mathrm{N}, 24^{\circ} \mathrm{E}\right)$ & 1998-2002 & 2 & 1.34 & 1.57 \\
\hline Lista, Norway $\left(58^{\circ} \mathrm{N}, 6^{\circ} \mathrm{E}\right)$ & 2000-2003 & 2 & 1.68 & 1.63 \\
\hline Råö, Sweden $\left(57^{\circ} \mathrm{N}, 11^{\circ} \mathrm{E}\right)$ & 2001 & 2 & 1.66 & 1.67 \\
\hline Rörvik, Sweden $\left(57^{\circ} \mathrm{N}, 25^{\circ} \mathrm{E}\right)$ & 2001-2002 & 2 & 1.66 & 1.70 \\
\hline Zingst, Germany $\left(54^{\circ} \mathrm{N}, 12^{\circ} \mathrm{E}\right)$ & 2000 & 2 & 1.56 & 1.84 \\
\hline Mace Head, Ireland $\left(54^{\circ} \mathrm{N}, 10^{\circ} \mathrm{W}\right)$ & 1995-2001 & 3 & 1.75 & 1.79 \\
\hline Langenbrügge, Germany $\left(52^{\circ} \mathrm{N}, 10^{\circ} \mathrm{E}\right)$ & 2002 & 2 & 1.70 & 1.84 \\
\hline Cheeka Peak, USA $\left(48^{\circ} \mathrm{N}, 125^{\circ} \mathrm{W}\right)$ & $2001-2002$ & 5 & 1.56 & 1.61 \\
\hline Detroit, USA $\left(43^{\circ} \mathrm{N}, 84^{\circ} \mathrm{W}\right)$ & 2003 & 6 & 2.2 & 1.9 \\
\hline Chongqing, China $\left(29^{\circ} \mathrm{N}, 106^{\circ} \mathrm{E}\right)$ & 2006-2007 & 7 & 6.7 & 4.9 \\
\hline Beijing, China $\left(40^{\circ} \mathrm{N}, 116^{\circ} \mathrm{E}\right)$ & 2005 & 8 & 4.9 & 3.9 \\
\hline Tokyo, Japan $\left(35^{\circ} \mathrm{N}, 135^{\circ} \mathrm{E}\right)$ & 2000-2001 & 9 & 2.80 & 2.54 \\
\hline New York, USA $\left(42^{\circ} \mathrm{N}, 73^{\circ} \mathrm{W}\right)$ & 2000-2003 & 10 & 2.3 & 1.93 \\
\hline Seoul, Korea $\left(36^{\circ} \mathrm{N}, 128^{\circ} \mathrm{E}\right)$ & 2003 & 11 & 5.0 & 4.7 \\
\hline Cape Point, South Africa $\left(34^{\circ} \mathrm{S}, 19^{\circ} \mathrm{E}\right)$ & 1998-2002 & 12 & 1.25 & 4.1 \\
\hline Neumayer, Antarctica $\left(70^{\circ} \mathrm{S}, 8^{\circ} \mathrm{W}\right)$ & 2000 & 3 & 1.06 & 1.26 \\
\hline St. Andrews, Canada $\left(45^{\circ} \mathrm{N}, 67^{\circ} \mathrm{W}\right)$ & 1998-2002 & 13 & 1.42 & 1.41 \\
\hline Fort Chipewyan, Canada $\left(59^{\circ} \mathrm{N}, 111^{\circ} \mathrm{W}\right)$ & 2000-2001 & 13 & 1.36 & 1.34 \\
\hline
\end{tabular}

* 1 Environmental Canada (2007); ${ }^{2}$ EMEP (2005); ${ }^{3}$ Ebinghaus et al. (2002); ${ }^{4}$ Kellerhals et al. (2003); ${ }^{5}$ Weiss-Penzias et al. (2003); ${ }^{6}$ Liu et al. (2007); ${ }^{7}$ Yang et al. (2009); ${ }^{8}$ Wang et al. (2006); ${ }^{9}$ Sakata and Marumoto (2002); ${ }^{10}$ Han et al. (2004); ${ }^{11}$ Kim et al. (2009); ${ }^{12}$ Slemr et al. (2008); ${ }^{13}$ Temme et al. (2007).

out of the total 21 sites, where model biases are smaller than $0.3 \mathrm{ng} \mathrm{m}^{-3}$. Larger positive biases $\left(3 \mathrm{ng} \mathrm{m}^{-3}\right)$ occur at the Cape Point site in South Africa, where mining industry development dominates the regional mercury emissions, accounting for a quarter of the total global anthropogenic emissions (Pacyna et al., 2006). However, the latest measurements indicate that the TGM concentration at the Cape Point site is around $1.25 \mathrm{ng} \mathrm{m}^{-3}$ (Slemr et al., 2008), which is much lower than our model results. Slemr et al. (2008) pointed out that the emission data set used in this study is the main reason for the large bias of mercury concentration in South Africa (Leaner et al., 2009; Masekoameng et al., 2010; Brunke et al., 2012). The overestimation in mercury emissions by Pacyna et al. (2006) is based on a problematic assumption that amalgamation is the dominant technology used in gold mining in South Africa whereas, in reality, the cyanide extraction technology is used, which emits hardly any mercury (Brunke et al., 2012). In addition, Witt et al. (2010) show that the prevailing strong westerly winds in near surface layers bring cleaner marine air rather than inland polluted air to Cape Point, effectively diluting mercury pollution. The coarse resolution CAM-Chem/Hg model has limited capability to simulate this westerly wind, which may also lead to large positive biases at Cape Point. On the other hand, the model tends to underestimate the TGM concentrations at 4 Asian sites
(Chongqing, Beijing, Tokyo, and Seoul) likely because the emissions there have likely continued to increase after year 2000. The model biases at these sites are less than $20 \%$ relative to the observations (Sakata and Marumoto, 2002; Kim et al., 2009; Wang et al., 2007; Yang et al., 2009).

Figure 3 illustrates the CAM-Chem/ $\mathrm{Hg}$ model simulated zonally and annually averaged surface air TGM concentration variations for 1999-2001 compared to observations at various locations worldwide, including land stations (Ebinghaus et al., 2002; Slemr et al., 2008; Sakata and Marumoto, 2002; Kellerhals et al., 2003; Weiss-Penzias et al., 2003; Environmental Canada 2003; Han et al., 2004; EMEP, 2005; Kim et al., 2009; Wang et al., 2007; Liu et al., 2007; Yang et al., 2008) and ocean cruises (Selin et al., 2007; Temme et al., 2003; Laurier et al., 2003; Lamborg et al., 1999). Note that these measurements are not necessarily representative of zonally and annually averaged conditions, but are used to depict the available variations with latitude. All of the land station data and the corresponding CAM-Chem $/ \mathrm{Hg}$ model values listed in Table 2 are also shown in Fig. 3. In general, the model captures the major TGM characteristic variation with latitude, following the variation of mercury emission sources. In particular, two peak values occur in the northern and southern middle latitudes that correspond to the intensive sources from industrial and mining activities. Due to 


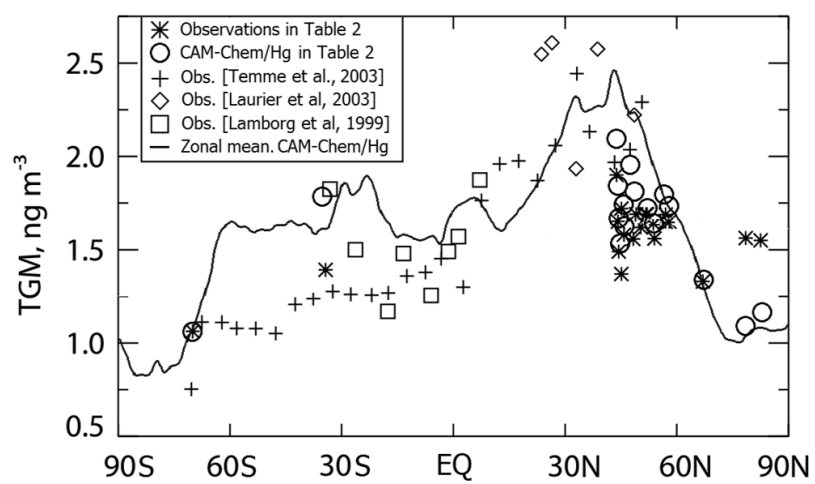

Fig. 3. Variation of TGM surface concentrations with latitude. Zonally averaged and annual mean CAM-Chem/Hg model results (curve) are compared to observations (symbols) from previous studies. The observations on land-based stations and corresponding CAM-Chem/Hg values are from Table 2. Reported measurements over the oceans are from Temme et al. (2003), Laurier et al. (2003) and Lamborg et al. (1999).

the relatively even distribution of mercury emissions from oceans, the variations of zonally averaged TGM concentrations tend to be associated with the amount of land fraction as a function of latitude.

In comparison, the GEOS-Chem model simulates a range between 1.25 and 1.75 for zonal mean surface air TGM concentrations (Selin et al., 2007) with latitude. The CAM$\mathrm{Chem} / \mathrm{Hg}$ model values are larger than this at lower and middle latitudes, but smaller at high latitudes. As explained by Selin et al. (2007), the Artic concentrations may be overestimated by the GEOS-Chem model due to missing halogen chemistry. The larger CAM-Chem/Hg model values in the northern middle latitudes are mainly attributed to high surface concentrations over East Asia as confirmed from the observations. In contrast, the results for the southern middle latitudes may be overestimated by the CAM-Chem $/ \mathrm{Hg}$ model due to uncertainties in the southern African emissions and meteorology (e.g., Cape Point site in Table 2).

Figure 4 compares the CAM-Chem/Hg modeled vertical profile of $\operatorname{Hg}(0)$ mixing ratios with aircraft measurements and its standard deviations from the Intercontinental Chemical Transport Experiment-B (INTEX-B), Arctic Research of the Composition of the Troposphere from Aircraft and Satellites (ARCTAS) and NOAA Tennessee (TN) campaigns (Talbot et al., 2008; Mao et al., 2010; Ren et al., 2013). The collection of measurements includes a good coverage of tropical, subtropical and polar profiles, which provides a comprehensive evaluation of model performance. Mexico and Pacific observations are made by INTEX-B during March 2006 and over the North Pacific Ocean for April-May 2006 (Talbot et al., 2008; Swartzendruber et al., 2008; Singh et al., 2009). The INTEX-B measurements are previously used by Holmes et al. (2010) with an increase of $40 \%$ based on
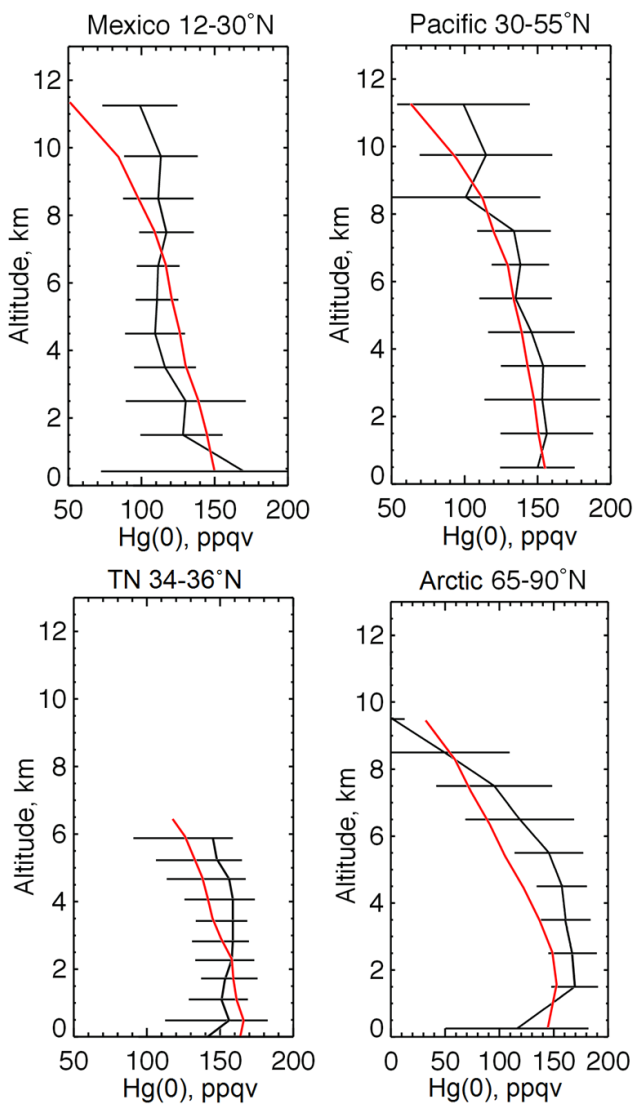

Fig. 4. Model results compared with aircraft measured vertical profiles of $\mathrm{Hg}(0)$ mixing ratios and its standard deviations. Mexico and Pacific observations are made by INTEX-B during March 2006 and over the North Pacific Ocean for April-May 2006 (Talbot et al., 2008; Swartzendruber et al., 2008; Singh et al., 2009). Tennessee (TN) observations are made near to Tullahoma $\left(35^{\circ} 23^{\prime} \mathrm{N}\right.$, $86^{\circ} 15^{\prime} \mathrm{W}$ ), by the NOAA air resource laboratory from August 2012 to February 2013 (Ren et al., 2013). Arctic observations are made by ARCTAS flights over the Arctic Ocean in spring $2008\left(65-90^{\circ} \mathrm{N}\right)$ (Mao et al., 2010).

the intercomparison by Swartzendruber et al. (2008). The model captures the trend of vertical variation of $\mathrm{Hg}(0)$ over tropical Mexico and the subtropical Pacific Ocean presented by measurements. The vertical decline in the model result is a little steeper than that in measurements. Similar features from NOAA TN measurements are also captured by the CAM-Chem/Hg model. The TN measurements are operated by NOAA air resources laboratory, which provide a consistent and high quality data set (Ren et al., 2013). However, a general problem in comparisons with low and middle latitude measurements is that the model cannot reproduce the near-constant concentrations $2-6 \mathrm{~km}$ above the ground. This may be caused by stronger oxidations of elemental mercury in the ozone-oxidation mechanism based model (Subir et al., 2011). ARCTAS flights provide unique observations of the Arctic region, the spring vertical profile is compared with 
model results on the same area. We found that the CAM$\mathrm{Chem} / \mathrm{Hg}$ model captures well the vertical variation, which is not captured by the model based on a Br oxidation mechanism (Holmes et al., 2010). Due to the ozone-oxidation mechanism used in the present CAM-Chem/ $\mathrm{Hg}$ model, the abundant ozone from upper troposphere and lower stratosphere may play an important role in reproducing this vertical profile.

Figure 5 compares the CAM-Chem/Hg modeled and observed seasonal variations of surface TGM concentrations at two coastal monitoring sites: Mace Head, Ireland, and Zingst, Germany (see the location information in Table 2). These two sites have made continuous measurements, with well characterized accuracy and precision. The monthly means are averaged in 1998-2004 for the observations (Kock et al., 2005) and in 1999-2001 for the model's results. Both sites were observed to have TGM levels higher in winter than in summer. This seasonality is captured by the CAM$\mathrm{Chem} / \mathrm{Hg}$ model. At Zingst, the model's result is closely comparable with the observations for February-August, but approximately $10 \%\left(0.2 \mathrm{ng} \mathrm{m}^{-3}\right)$ lower for the other months. Model underestimations of a similar magnitude occur at Mace Head throughout the year. Note that air pollution at coastal sites in midlatitudes can be strongly affected by land or sea breezes. In summer, warmer land than ocean temperatures cause prevailing onshore winds. As such, measurements at coastal sites may be affected more by oceanic than inland mercury levels. The winter conditions generally reverse. This effect is challenging to simulate, especially using a relatively coarse resolution model such as CAM-Chem that cannot accurately represent local circulation patterns. However, the wet deposition measurements suggest that the removal of atmospheric mercury is high in summer at most non-coastal sites over the contiguous US (NADP, 2008), which would be a reason to understand this pattern. At this time, it is not known whether the above disagreements are caused by differences in local source emissions or meteorological conditions.

\subsection{Results by adding bromine oxidation}

In order to test how the bromine oxidation reactions affect the mercury distributions, we add the bromine chemical reactions in both gas and aqueous phases (as shown in Table 1) in addition to the $\mathrm{O}_{3}-\mathrm{OH}$ oxidation mechanism. The experiment is implemented by directly using the monthly averaged $\mathrm{Br}$ concentrations from the GEOS-Chem mercury model. The evaluation of GEOS-Chem simulations of $\mathrm{Br}$ chemicals shows good agreement with available aircraft observations (Parrella et al., 2012). The annual mean Br mixing ratio from GEOS-Chem peaks in higher latitude ocean regions but is generally low over land. The seasonality shows high levels for March-May and September-November. Similar to the CAM-Chem $/ \mathrm{Hg}$ simulation, the modified model is driven by NCEP reanalysis meteorology and runs for $2 \mathrm{yr}$, from 1999
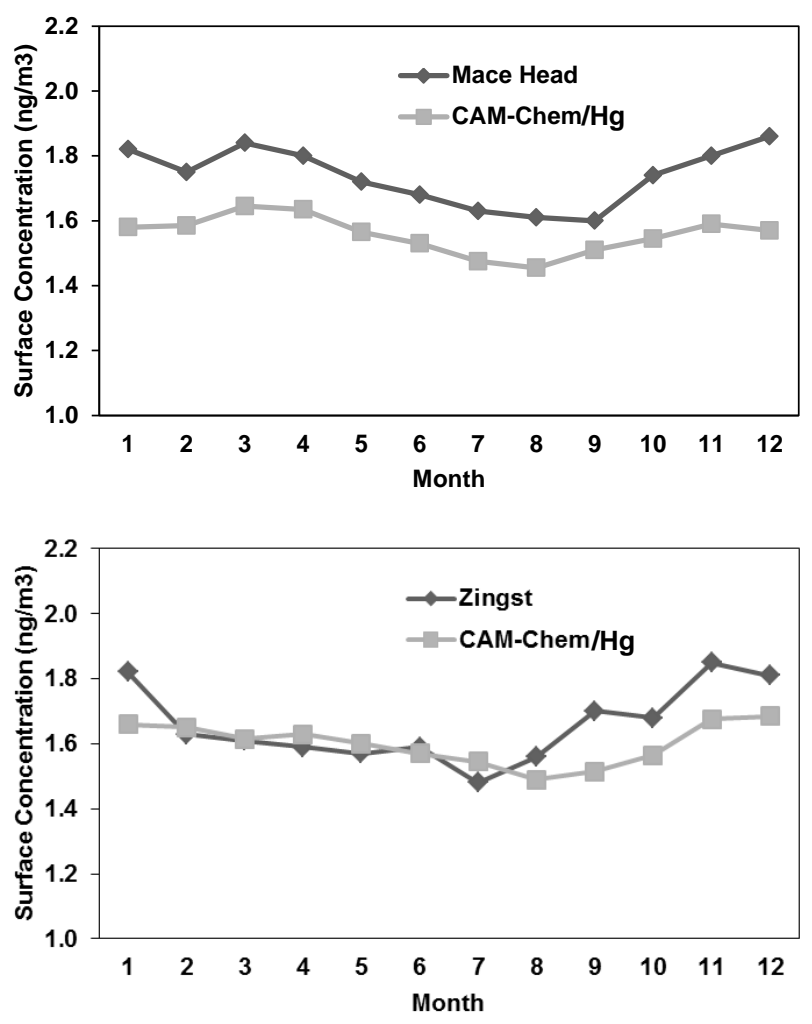

Fig. 5. Seasonal variations of surface atmospheric TGM concentrations $\left(\mathrm{ng} \mathrm{m}^{-3}\right)$ at coastal stations: Mace Head, Ireland, and Zingst, Germany. Shown are monthly means averaged in 1998-2004 for observations and 1999-2001 for CAM-Chem/Hg.

to 2000. The first year run is considered as a model spin-up, and the second year (2000) data is used to compare with the CAM-Chem/Hg simulation of 2000.

Figure 6 shows the change in TGM concentration on the surface layer resulting from introduced bromine reactions. Generally, adding bromine chemistry appears to have little impact on overall TGM spatial and temporal patterns with less than a $0.2 \mathrm{ng} \mathrm{m}^{-3}$ decrease found in most areas across the globe. The additional bromine reactions will accelerate the transformation of $\operatorname{Hg}(0)$ to $\mathrm{RGM}$, the part of which will be counted into TGM. We also notice that regions with large emission and precipitation tend to have larger TGM reduction. This is because bromine chemistry transforms more $\mathrm{Hg}(0)$ into RGM, which subsequently enhances the wet deposition of $\mathrm{Hg}(\mathrm{II})$, leading to the reduced TGM concentration. Theoretically, bromine may increase the TGM in some places where the reduction reactions become more significant (more RGM is reduced to $\mathrm{Hg}(0)$, leading to less wet deposition loss from the atmosphere). However, it is not shown in this experiment.

Overall, including the bromine chemistry does not significantly affect the TGM pattern, but it may affect the gaseous mercury partitioning between the elemental mercury and 


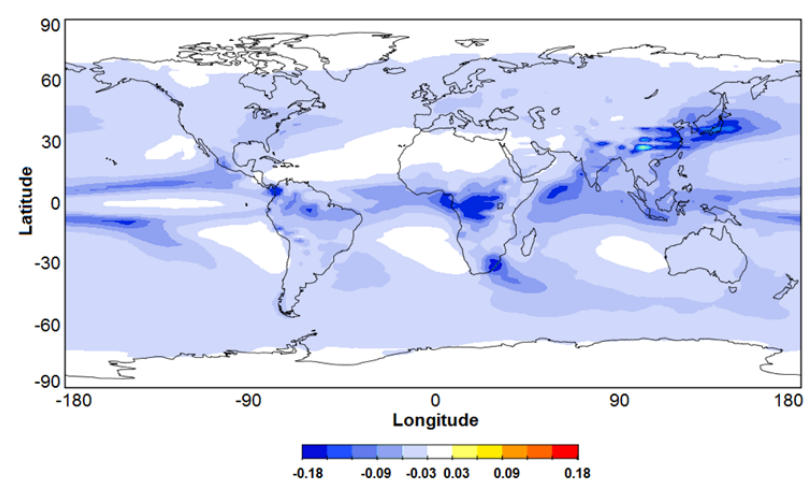

Fig. 6. Change in TGM concentration $\left(\mathrm{ng} \mathrm{m}^{-3}\right)$ on the surface layer by introducing bromine chemistry.

reactive gaseous mercury. Due to the difficulty in monitoring gaseous $\mathrm{Hg}(\mathrm{II})$, our knowledge on $\mathrm{Hg}(0) / \mathrm{Hg}$ (II) partitioning is limited and needs further investigation (NADP, 2008). It is also noted that kinetic coefficients for $\mathrm{Hg}(0)$ reactions with $\mathrm{OH}, \mathrm{O}_{3}$ and $\mathrm{Br}$ are uncertain. If the coefficients are much slower than assumed in this modeling work, then $\mathrm{Br}$ chemistry may have a larger impact on TGM and $\mathrm{Hg}$ cycling. In the following sections, we continue analyses of the CAM$\mathrm{Chem} / \mathrm{Hg}$ simulated results without considering the possible effects of bromine chemistry.

\section{US mercury wet deposition}

Wet deposition is mainly determined by the distribution of precipitation amount and air pollutant concentration. Previous regional modeling studies suggested that mercury wet deposition over the US also depended on the mercury emissions used (Bullock and Brehme, 2002; Gbor et al., 2005). Table 3 compares the modeled annually averaged wet depositions for total mercury with the measurements at 26 monitoring sites of the Mercury Deposition Network (MDN) within the US National Atmospheric Deposition Program (NADP). The model values are averaged over 1999-2001, while observations are given as the means of all measurements during the most closely matching data periods. The results show that the CAM-Chem $/ \mathrm{Hg}$ simulation is realistic at 18 of the 26 sites, where differences from observations are within $\pm 20 \%$. However, at some coastal sites (FL11, WA18), model biases are as large as $6 \mu \mathrm{g} \mathrm{m}^{-2}$. These differences are likely caused by errors in simulating precipitation near the coast by the CAM-Chem model with its coarse resolution. In addition, relative biases are larger at some sites (e.g., CA72) with low wet depositions. The differences in data periods may partially explain the model-observation discrepancies.

Figure 7 illustrates the geographic distribution of wet deposition for annually averaged total mercury for 19992001 over the US as derived by the CAM-Chem/Hg model. The spatial pattern of mercury wet deposition follows more

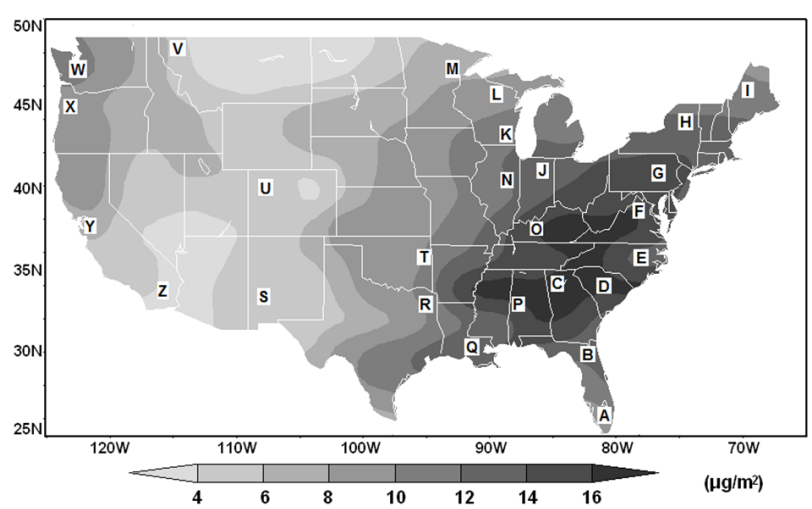

Fig. 7. Annual total mercury wet deposition $\left(\mu \mathrm{g} \mathrm{m}^{-2}\right)$ averaged for 1999-2001 as simulated by the CAM-Chem/Hg. Letters represent the MDN monitoring sites in Table 3.

closely to that of precipitation (Liang et al., 2004) than of the atmospheric mercury concentration. In general, the largest wet deposition occurs in the eastern US, where the peaks correspond to the maximum annual precipitation centers over the southeast. Although it is also located on the southwestern flank of the TGM concentration maxima, more related are the oxidized mercury (RGM and PHg). This is because the precipitation mainly removes RGM and $\mathrm{PHg}$ from the atmosphere, while the TGM is hardly susceptible to wet scavenging. The secondary peaks of annual total mercury wet depositions are simulated over the northwest, where precipitation prevails during cold seasons.

Figure 8 presents the scatter diagrams comparing modeled monthly total mercury wet deposition for 1999-2001 at the four MDN sites with the best availability and consistence of records, representing the southeast (FL11), eastern coast (NC42), midwest (WI08), and southwest (TX21). The temporal correlation coefficients between modeled and measured depositions are reasonably high, suggesting that the CAM$\mathrm{Chem} / \mathrm{Hg}$ model largely captures observational variations at each site. The best result is obtained in the midwest, where the correlation reaches 0.67 . The result is also good for the southeast and fair for the southwest, with a respective correlation of 0.45 and 0.32 , but relatively poor for the east coast with a low correlation of 0.19 . The model results tends to better capture the variability on sites in regions with less anthropogenic impacts (WI08 and FL11), which indicates that anthropogenic emission is a significant source for bias. Possible biases in model representation of precipitations and a coarse global model grid would also affect this comparison.

\section{Domestic versus transpacific contributions to US mercury air quality}

The transpacific transport is the primary process for bringing Asian pollutants to the US. Various ground-level observation 
Table 3. CAM-Chem/Hg modeled annual total mercury wet depositions as compared with measurements at the selected monitoring sites of the NADP MDN.

\begin{tabular}{|c|c|c|c|c|}
\hline Site & Location (Lat, Lon) & Observation years & $\operatorname{NADP}\left(\mu \mathrm{g} \mathrm{m}^{-3}\right)$ & Model (1999-2001) $\left(\mu \mathrm{g} \mathrm{m}^{-3}\right)$ \\
\hline A (FL11) & $\left(25.39^{\circ} \mathrm{N}, 80.68^{\circ} \mathrm{W}\right)$ & 1998-2002 & 17.9 & 11.9 \\
\hline $\mathrm{B}(\mathrm{GA} 09)$ & $\left(30.74^{\circ} \mathrm{N}, 82.13^{\circ} \mathrm{W}\right)$ & 1998-2002 & 12.3 & 12.5 \\
\hline $\mathrm{C}(\mathrm{GA} 40)$ & $\left(33.93^{\circ} \mathrm{N}, 85.05^{\circ} \mathrm{W}\right)$ & $2001-2003$ & 17.7 & 18.2 \\
\hline $\mathrm{D}(\mathrm{SC} 19)$ & $\left(33.81^{\circ} \mathrm{N}, 80.78^{\circ} \mathrm{W}\right)$ & 1998-2002 & 12.7 & 15.9 \\
\hline $\mathrm{E}(\mathrm{NC} 42)$ & $\left(35.74^{\circ} \mathrm{N}, 76.51^{\circ} \mathrm{W}\right)$ & $1998-2002$ & 11.2 & 13.1 \\
\hline F(VA28) & $\left(38.52^{\circ} \mathrm{N}, 78.43^{\circ} \mathrm{W}\right)$ & 2003-2005 & 13.2 & 14.7 \\
\hline G(PA47) & $\left(39.99^{\circ} \mathrm{N}, 76.38^{\circ} \mathrm{W}\right)$ & $2003-2005$ & 11.6 & 14.3 \\
\hline H(NY20) & $\left(43.97^{\circ} \mathrm{N}, 74.22^{\circ} \mathrm{W}\right)$ & 2000-2002 & 9.1 & 12.1 \\
\hline I(ME98) & $\left(44.38^{\circ} \mathrm{N}, 68.26^{\circ} \mathrm{W}\right)$ & 1998-2002 & 7.2 & 10.3 \\
\hline $\mathrm{J}(\mathrm{IN} 20)$ & $\left(40.84^{\circ} \mathrm{N}, 85.46^{\circ} \mathrm{W}\right)$ & 2001-2003 & 12.2 & 12.3 \\
\hline $\mathrm{K}(\mathrm{WI} 22)$ & $\left(43.07^{\circ} \mathrm{N}, 87.88^{\circ} \mathrm{W}\right)$ & $2003-2005$ & 10.1 & 10.8 \\
\hline L(WI08) & $\left(46.75^{\circ} \mathrm{N}, 91.61^{\circ} \mathrm{W}\right)$ & 1998-2002 & 7.7 & 9.2 \\
\hline $\mathrm{M}(\mathrm{MN} 23)$ & $\left(46.25^{\circ} \mathrm{N}, 94.50^{\circ} \mathrm{W}\right)$ & 1998-2002 & 7.3 & 6.7 \\
\hline $\mathrm{N}(\mathrm{IL} 11)$ & $\left(40.05^{\circ} \mathrm{N}, 88.37^{\circ} \mathrm{W}\right)$ & 1999-2002 & 9.3 & 10.1 \\
\hline $\mathrm{O}(\mathrm{KY} 10)$ & $\left(37.13^{\circ} \mathrm{N}, 86.15^{\circ} \mathrm{W}\right)$ & $2003-2005$ & 11.7 & 15.7 \\
\hline P(AL03) & $\left(32.90^{\circ} \mathrm{N}, 87.25^{\circ} \mathrm{W}\right)$ & $2001-2003$ & 13.6 & 14.2 \\
\hline $\mathrm{Q}(\mathrm{LA} 28)$ & $\left(30.50^{\circ} \mathrm{N}, 90.38^{\circ} \mathrm{W}\right)$ & 1999-2002 & 15.8 & 13.3 \\
\hline $\mathrm{R}(\mathrm{TX} 21)$ & $\left(32.38^{\circ} \mathrm{N}, 94.71^{\circ} \mathrm{W}\right)$ & 1998-2002 & 12.3 & 11.4 \\
\hline S(NM10) & $\left(33.06^{\circ} \mathrm{N}, 107.29^{\circ} \mathrm{W}\right)$ & 1998-2002 & 4.1 & 4.7 \\
\hline T(OK99) & $\left(35.75^{\circ} \mathrm{N}, 94.67^{\circ} \mathrm{W}\right)$ & 2003-2005 & 13.7 & 10.5 \\
\hline U(CO97) & $\left(40.54^{\circ} \mathrm{N}, 106.68^{\circ} \mathrm{W}\right)$ & 1999-2002 & 6.8 & 5.7 \\
\hline V(MT05) & $\left(48.51^{\circ} \mathrm{N}, 114.00^{\circ} \mathrm{W}\right)$ & 2004-2006 & 5.7 & 5.9 \\
\hline W(WA18) & $\left(47.68^{\circ} \mathrm{N}, 122.26^{\circ} \mathrm{W}\right)$ & 1998-2002 & 6.2 & 10.4 \\
\hline $\mathrm{X}(\mathrm{OR} 10)$ & $\left(44.21^{\circ} \mathrm{N}, 122.25^{\circ} \mathrm{W}\right)$ & 2003-2005 & 7.8 & 8.6 \\
\hline $\mathrm{Y}(\mathrm{CA} 72)$ & $\left(37.43^{\circ} \mathrm{N}, 122.06^{\circ} \mathrm{W}\right)$ & 2000-2002 & 3.6 & 6.7 \\
\hline Z(CA97) & $\left(39.82^{\circ} \mathrm{N}, 123.24^{\circ} \mathrm{W}\right)$ & 1998-2002 & 3.2 & 3.8 \\
\hline
\end{tabular}

analyses, field campaigns, and model simulations have been conducted to investigate the current pathways and characteristics of transpacific transport, as well as their influence on US air quality (e.g., Jacob et al., 1999; Wilkening et al., 2000; Yienger et al., 2000; Jaeglé et al., 2003; Hudman, 2004; Parrish et al., 2004; Bertschi and Jaffe, 2005; Heald et al., 2008; Wuebbles et al., 2007). Previous sections have shown that the mercury pollution in East Asia is the most severe in the world. Therefore, analysis of the contributions from transpacific transport on US mercury air quality is worth investigating.

Two sensitivity experiments for the years 1998-2001 are conducted to examine the domestic versus international contributions to US mercury concentrations. The first sensitivity experiment (EXP1) assumes no anthropogenic emissions over the United States and uses the current model settings elsewhere. The second sensitivity experiment (EXP2) assumes no anthropogenic emissions over Asia and keeps the current settings elsewhere. Simulations of global mercury concentrations in the previous section are used as the control run (CtrRun) to present the practical mercury effects on air quality.

Figure 9 shows the CAM-Chem simulated total mercury dispersion ratios (Asia-Hg/Global-Hg) at the low $(2-3 \mathrm{~km})$ and middle (5-6 km) troposphere for 1999-2001. Contributions of Asian mercury emissions to total mercury dispersions on each level are calculated from CtrRun minus EXP2. The ratio in the lower troposphere has a contribution rate of around 0.3 in the western US, while the ratio in the middle troposphere shows a larger contribution rate near 0.4. This result indicates that relatively stronger transport of mercury occurs in the middle troposphere than that in the lower troposphere. The pattern also suggests that the transpacific transport of mercury is strong between 30 and $55^{\circ} \mathrm{N}$.

Surface TGM concentrations are directly affected by transpacific transport. The top panels in Fig. 10 show the contributions to TGM concentrations from domestic (CtrRunEXP1 (TGM)) and transpacific transported (CtrRun-EXP2 (TGM)) anthropogenic sources respectively. Domestic anthropogenic emissions contribute $0.2-0.9 \mathrm{ng} \mathrm{m}^{-3}$ to the total surface TGM over the western US and $0.2-1.1 \mathrm{ng} \mathrm{m}^{-3}$ over the eastern US. Contributions from transpacific transport mainly focus on the western US with a magnitude of $0.16-0.32 \mathrm{ng} \mathrm{m}^{-3}$. However, the contributions to the eastern US are below $0.16 \mathrm{ng} \mathrm{m}^{-3}$. This pattern follows the expected effect of transpacific transport on ozone (Lin et al., 2008). Relatively, domestic anthropogenic emissions are the 

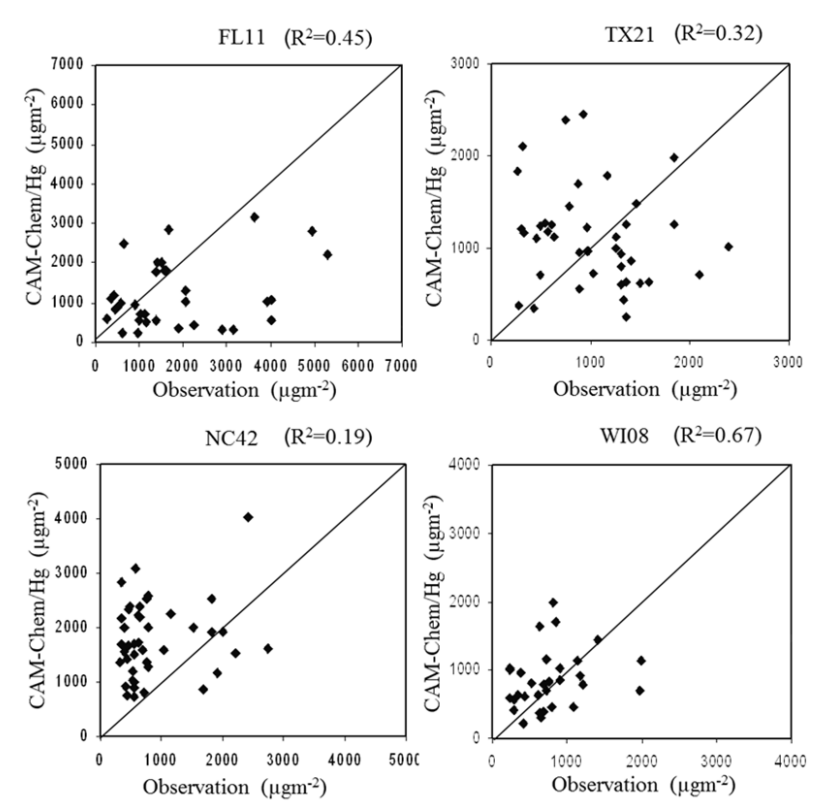

Fig. 8. Scatter diagrams comparing modeled and measured monthly total mercury wet depositions for 1999-2001 at four MDN sites. The temporal squared correlation coefficients are also listed for each site.

dominant anthropogenic sources, contributing around $25 \%$ of total gaseous mercury concentrations on a national basis.

The bottom panels in Fig. 10 show the contributions to total annual mercury deposition (dry and wet) by domestic (CtrRun-EXP1 (Deposition)) versus transpacific transported (CtrRun-EXP2 (Deposition)) anthropogenic emissions. Domestic anthropogenic emissions contribute $6-12 \mu \mathrm{g} \mathrm{m}^{-2}$ to the total surface TGM deposition over the eastern US and generally below $7 \mu \mathrm{g} \mathrm{m}^{-2}$ over the western US. The highest contributions are over the midwest. The domestic anthropogenic emissions contribute on average $22 \%$ to total deposition in the United States, but near 50\% in the industrial regions. This result is consistent with previous modeling studies by Seigner et al. (2004) and Selin et al. (2008). Contributions from transpacific transport to total mercury deposition in the US are $1-4 \mu \mathrm{g} \mathrm{m}^{-2}$ over the western US, but below $2 \mu \mathrm{g} \mathrm{m}^{-2}$ over the eastern US. The pattern is consistent with the contributions to TGM concentrations. In addition, it is noted that there is more deposition in the western US from domestic sources, but that Asian sources contribute significantly.

\section{Summary and conclusion}

A tropospheric mercury chemistry module has been developed and incorporated into the CAM-Chem model to represent the processes affecting atmospheric mercury and its deposition over the globe. It includes the chemistry, emission,
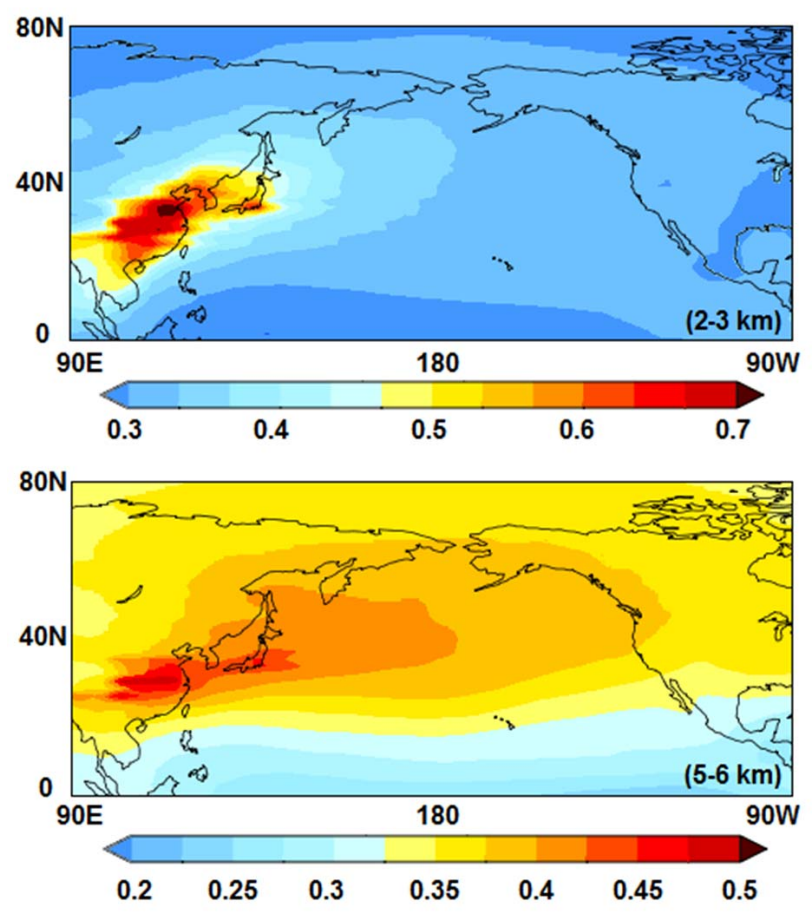

Fig. 9. Average dispersion ratio: Asia-Hg / Global-Hg at the low (2$3 \mathrm{~km}$ ) and middle (5-6 km) troposphere for 1999-2001.

deposition, and transport processes for elemental, reactive, and particulate forms of mercury. The chemistry considers the oxidation of elemental mercury by ozone with temperature dependence, the oxidation by $\mathrm{OH}$, hydrogen peroxide and chlorine in gaseous phase, as well as the aqueous reduction and oxidation on mercury species. The transport and deposition of mercury are determined using the approaches used for other chemicals in the CAM-Chem model. Mercury emissions are included based on published estimates for human-related, volcano eruption, and biomass burning sources, as well as the dynamic parameterizations for natural sources, including air-sea exchanges from oceans and land surfaces (soil, vegetation), and reemissions depending on the temperature, solar radiation and soil storage. The total emission of mercury at the present climate condition is estimated to be $9600 \mathrm{Mg} \mathrm{yr}^{-1}$ over the globe, of which 2200,2900 , 3400,600 , and $500 \mathrm{Mg} \mathrm{yr}^{-1}$ are from respectively anthropogenic, land, ocean, biomass burning and volcano sources. The atmospheric lifetime of mercury against deposition is approximately $0.69 \mathrm{yr}$ in the absence of recycling from surface reemissions. In our model, the dynamic schemes for land and ocean emissions are simplified from the previous dynamic models for point source emission, and then calibrated by the latest estimate on present global natural emissions based on observations. This solution not only considers the physical processes associated with natural emissions, but also includes the latest knowledge on it. Compared with the original approaches, both simplified schemes also save substantial 

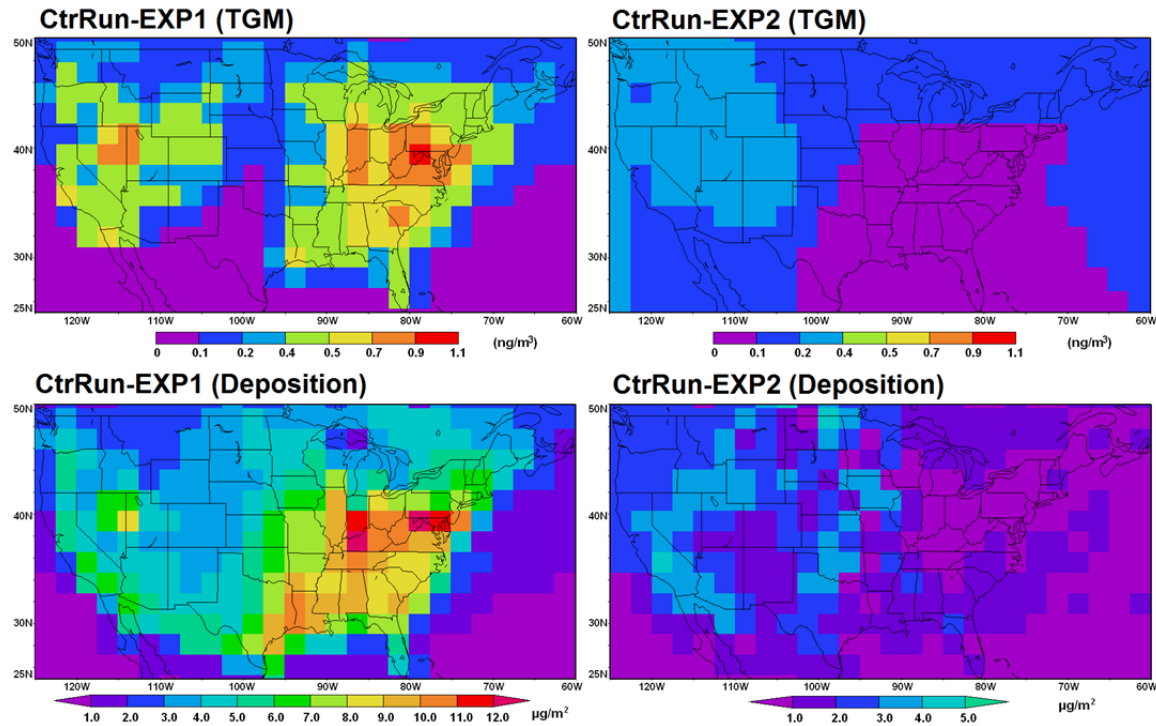

CtrRun-EXP2 (Deposition)

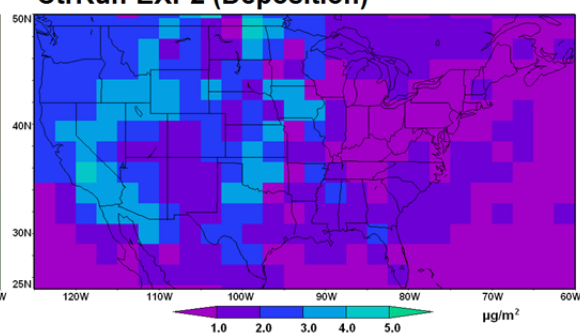

Fig. 10. Sensitivity experiments for domestic versus transpacific contributions to annual mean atmospheric concentration and deposition of mercury in the US. CtrRun-EXP1 (TGM): contributions of domestic anthropogenic emissions of mercury on TGM concentrations. CtrRunEXP2 (TGM): contributions of transpacific anthropogenic emissions of mercury on TGM concentrations. CtrRun-EXP1 (Deposition): contributions of domestic anthropogenic emissions of mercury on deposition of total mercury. CtrRun-EXP2 (Deposition): contributions of transpacific anthropogenic emissions of mercury on deposition of total mercury.

amounts of computational time. Although our approach appears to provide a good approximation of current knowledge on the reemission process, uncertainties such as the influence from meteorologic factors other than temperature and solar radiation and the role of vegetation coverage remain that require further analysis.

The CAM-Chem/Hg model has been evaluated relative to the available measurements worldwide using meteorological conditions driven from the NCEP observational reanalysis. The evaluation includes both surface air TGM concentrations and annual total mercury wet depositions. They are compared with observations: 21 land sites distributed evenly over the globe along with 3 ocean cruise tracks are used for evaluating concentrations, and 26 US monitoring sites are used for evaluating the wet deposition. For both quantities, the model captures the major characteristics of their geographic distributions and seasonal variations. As a result of these many analyses, we conclude that the CAM-Chem/Hg is a reasonable and reliable modeling tool to study the physical and chemical processes governing the emission, transport, transformation and deposition of atmospheric mercury. At the same time, we recognize that the model needs further improvement. From the modeling successes and failures in the comparison against measurements, we found the emission inventory to be the major source for model biases. For example, the high mercury concentrations on South Africa and over ocean upwelling regions are associated with overestimations in emission data. Further study using different mercury emission inventories in the same mercury model would better as- sess the emission inventory and modeling system. The representation of meteorology in the mercury model would be another uncertainty resulting in model biases. In particular, improvements are needed to reduce the large underestimations of wet depositions near the coastal regions where the precipitations are difficult to capture. The underestimation may also be associated with two other issues. One issue is our poor understanding of the $\mathrm{Hg}(0) / \mathrm{Hg}(\mathrm{II})$ redox chemistry including gaseous, aqueous and heterogeneous reactions, which could have an important effect on deposition patterns. The other issue is the wet deposition scheme, which may need to be modified to better account for mercury attachment on other aerosols or for electrostatic adherence on droplets. Any laboratory and/or field experiments to improve our understanding on these two issues would greatly enhance model performance.

In order to address the current debate on the mercury chemistry mechanism, we also incorporate the bromine mechanism into the CAM-Chem/ $\mathrm{Hg}$ in the combination to $\mathrm{O}_{3}-\mathrm{OH}$-oxidation mechanism. By using external bromine concentration data, a sensitivity experiment was set to test the possible impact of bromine reactions on mercury concentration distribution. The result shows that the effect of extra bromine reactions on TGM concentration is relatively small, but the effect on $\mathrm{Hg}(0) / \mathrm{Hg}$ (II) partitioning is significant although how partitioning occurs in the real atmosphere is still subject to further investigation. In reference to several recent studies, we conclude that $\mathrm{O}_{3}-\mathrm{OH}$ oxidation is still a 
reasonable mechanism for capturing mercury pollution with models.

The sensitivity study on effects of domestic emissions versus transpacific transport of anthropogenic mercury emissions on the concentrations of mercury compounds in the United States shows that, on a national basis, around $22 \%$ of total mercury deposition in the United States results from domestic anthropogenic sources, and only $9 \%$ is contributed by transpacific transport. However, the contributions to deposition on the western United States are of comparable magnitude, with around $50 \%$ from domestic sources and around $20 \%$ from transpacific sources. Domestic anthropogenic emissions are the dominant anthropogenic sources that contribute around $25 \%$ of total gaseous mercury concentrations on a national basis. The averaged contribution percentage to TGM concentrations from transpacific transport is only $7 \%$. These analyses provide improved understanding of the present US mercury concentrations and deposition, and the relationship between Asian and US mercury pollution. Another important issue is how the US mercury concentrations and this Asia-US relationship will likely change in the coming decades. A comprehensive understanding through further research on this issue would help policymakers in considering effective strategies regarding mercury pollution.

\section{Supplementary material related to this article is available online at http://www.atmos-chem-phys.net/13/ 10807/2013/acp-13-10807-2013-supplement.pdf.}

Acknowledgements. This research was supported in part by the US Environmental Protection Agency's Science to Achieve Results (STAR) Program under award number EPA RD-83337301. The authors acknowledge DOE/NERSC and NCSA/UIUC for the supercomputing support. We also thank Christopher Holmes for providing mercury emissions and bromine concentration data from the GEOS-Chem model and for valuable discussions on mercury simulations. Great appreciations to reviewers and the editor of this article. Their works significantly improve the quality of this article.

Edited by: A. Dastoor

\section{References}

Aiuppa, A., Bagnato, E., Witt, M. L. I., Mather, T. A., Parello, F., Pyle, D. M., and Martin, R. S.: Real-time simultaneous detection of volcanic $\mathrm{Hg}$ and $\mathrm{SO} 2$ at La Fossa Crater, Vulcano (Aeolian Islands, Sicily), Geophys. Res. Lett., 34, L21307, doi:10.1029/2007GL030762, 2007.

AMAP/UNEP: Technical Background Report to the Global Atmospheric Mercury Assessment. Arctic Monitoring and Assessment Programme / UNEP Chemicals Branch. 159, 2008. Online at: www.chem.unep.ch/mercury/Atmospheric_Emissions/ Technical_background_report.pdf

AMAP/UNEP: Technical Background Report for the Global Mercury Assessment 2013. Arctic Monitoring and Assessment Programme, Oslo, Norway/UNEP Chemicals Branch, Geneva, Switzerland. 2013.

Amyot, M., Southworth, G. L., Lindberg, S. E., Hintelmann, H., Lalonde, J. D., Ogrinc, N. P., Poulain, A. J., and Sandilands, K. A.: Formation and evasion of dissolved gaseous mercury in large enclosures amended with $200 \mathrm{HgCl} 2$, Atmos. Environ., 38, 42794289, 2004.

Balabanov, N., Shepler, B., and Peterson, K.: Accurate global potential energy surface and reaction dynamics for the ground state of $\mathrm{HgBr} 2$, J. Phys. Chem. A, 109, 8765-8773, 2005.

Bergan, T., Gallardo, L., and Rodhe, H.: Mercury in the global troposphere: a three-dimensional model study, Atmos. Environ., 33, 1575-1585, 1999.

Bertschi, I. T. and Jaffe, D. A.: Long-range transport of ozone, carbon monoxide, and aerosols to the NE Pacific troposphere during the summer of 2003, Observations of smoke plumes from Asian boreal fires, J. Geophys. Res., 110, D05303, doi:10.1029/2004JD005135, 2005.

Bullock, O. and Brehme, K.: Atmospheric mercury simulation using the CMAQ model: formulation description and analysis of wet deposition results, Atmos. Environ., 36, 2135-2146, 2002.

Bullock, O., Atkinson, D., Braverman, T., Civerolo, K., Dastoor, A., Davignon, D., Ku, J.-Y., Lohman, K., Myers, T. C., Park, R. J., Seigneur, C., Selin, N. E., Sistla, G., and Vijayaraghavan, K.: The North American Mercury Model Intercomparison Study (NAMMIS): study description and model-to-model comparisons, J. Geophys. Res., 113, D17310, doi:10.1029/2008JD009803, 2008.

Bullock, O., Atkinson, D., Braverman, T., Civerolo, K., Dastoor, A., Davignon, D., Ku, J.-Y., Lohman, K., Myers, T. C., Park, R. J., Seigneur, C., Selin, N. E., Sistla, G., and Vijayaraghavan, K.: An analysis of simulated wet deposition of mercury from the North American Mercury Model Intercomparison Study, J. Geophys. Res., 114, D08301, doi:10.1029/2008JD011224, 2009.

Brasseur, G., Kiehl, J., Müller, J.-F., Schneider, T., Granier, C., Tie, X., and Hauglustaine, D.: Past and future changes in global tropospheric ozone: impact on radiative forcing, Geophys. Res. Lett., 25, 3807-3810, 1998.

Brunke, E.-G., Ebinghaus, R., Kock, H. H., Labuschagne, C., and Slemr, F.: Emissions of mercury in southern Africa derived from long-term observations at Cape Point, South Africa, Atmos. Chem. Phys., 12, 7465-7474, doi:10.5194/acp-12-74652012, 2012.

Calhoun, J. and Prestbo, E.: Kinetic study of the gas phase oxidation of elemental mercury by molecular chlorine, Report available from Frontier Geosciences, Inc., 414 Pontius Avenue N., Seattle, WA 98109, 2001.

Calvert, J. and Lindberg, S.: Mechanisms of mercury removal by $\mathrm{O} 3$ and $\mathrm{OH}$ in the atmosphere, Atmos. Environ., 39, 3355-3367, doi:10.1016/j.atmosenv.2005.01.055, 2005.

Carpi, A. and Lindberg, S.: Application of a Teflon (TM) dynamic flux chamber for quantifying soil mercury flux: tests and results over background soil, Atmos. Environ., 32, 873-882, 1998.

Clean Air Act Amendments of 1990: Pub. L. 101-549, 104 Stat. 2399, H.R. 3030-101st Congress, available at: http://www. 
govtrack.us/congress/bills/101/hr3030 (last access: 9 February 2012), 1990.

Clever, H., Johnson, S., and Derrick, A.: The solubility of mercury and some sparingly soluble mercury salts in water and aqueous electrolyte solutions, J. Phys. Chem. Ref. Data, 14, 631-680, 1985.

Collins, W., Bitz, C., Blackmon, M., Bonan, G., Bretherton, C., Carton, J., Chang, P., Doney, S., Hack, J., Henderson, T., Kiehl, J., Large, W., McKenna, D., Santer, B., and Smith, R.: The Community Climate System Model Version 3 (CCSM3), J. Climate, 19, 2122-2143, doi:10.1175/JCLI3761.1, 2006.

Cohen, M., Artz, R., Draxler, R., Miller, P., Poissant, L., Niemi, D., Ratte, D., Deslauriers, M., Duval, R., Laurin, R., Slotnick, J., Nettesheim, T., and McDonald, J. Modeling the Atmospheric Transport and Deposition of Mercury to the Great Lakes, Environ. Res., 95, 247-265, 2004.

Donohoue, D., Bauer, D., Cossairt, B., and Hynes, A.: Temperature and pressure dependent rate coefficients for the reaction of $\mathrm{Hg}$ with $\mathrm{Br}$ and the reaction of $\mathrm{Br}$ with $\mathrm{Br}$ : a pulsed laser photolysispulsed laser induced fluorescence study, J. Phys. Chem. A, 110, 6623-6632, 2006.

Ebinghaus, R., Kock, H., Temme, C., Einax, J., Lowe, A., Richter, A., Burrows, J., and Schroeder, W.: Antarctic springtime depletion of atmospheric mercury, Environ. Sci. Technol., 36, 12381244, 2002.

EMEP MSC-W Technical Report: Atmospheric Supply of Nitrogen, Lead, Cadmium, Mercury and Dioxins/Furans to the Baltic Sea in 2003, European Monitoring and Evaluation Programme, http://emep.int/publ/helcom/2012/index.html (last access: 14 January 2013), 2005.

Emmons, L. K.,Walters, S., Hess, P. G., Lamarque, J.-F., Pfister, G. G., Fillmore, D., Granier, C., Guenther, A., Kinnison, D., Laepple, T., Orlando, J., Tie, X., Tyndall, G., Wiedinmyer, C., Baughcum, S. L., and Kloster, S.: Description and evaluation of the Model for Ozone and Related chemical Tracers, version 4 (MOZART-4), Geosci. Model Dev., 3, 43-67, doi:10.5194/gmd3-43-2010, 2010

Environment Canada: Proposed Risk Management Instruments for Mercury-Containing Products, Environment Canada, 2007.

European Monitoring and Evaluation Programme: CCC-Report 9/2001, http://www.nilu.no/projects/ccc/reports/cccr9-2001.pdf (last access: 9 February 2012), 2001.

Ferrara, R., Mazzolai, B., Lanzillotta, E., Nucaro, E., and Pirrone, N.: Volcanoes as emission sources of atmospheric mercury in the Mediterranean basin, Sci. Total Environ., 259, 115-121, 2000.

Friedli, H., Radke, L., Prescott, R., Li, P., Woo, J.-H., and Carmichael, G.: Mercury in the atmosphere around Japan, Korea and China as observed during the 2001 ACE Asia field campaign: measurements, distributions, sources, and implications, J. Geophys. Res., 109, D19S25, doi:10.1029/2003JD004244, 2004.

Gardfeldt, K., Sommar, J., Stromberg, D., and Feng, X.: Oxidation of atomic mercury by hydroxyl radicals and photoinduced decomposition of methylmercury in the aqueous phase, Atmos. Environ., 35, 3039-3047, 2001.

Gardfeldt, K. and Jonsson, M.: Is bimolecular reduction of $\mathrm{Hg}$ (II) complexes possible in aqueous systems of environmental importance, J. Phys. Chem., A 107, 4478-4482, 2003.
Gbor, P., Wen, D., Meng, F., Yang, F., Zhang, B., and Sloan, J.: Improved model for mercury emission, transport and deposition, Atmos. Environ., 40, 973-983, 2006.

Giorgi, F. and Chameides, W.: The rainout parameterization in a photochemical model, J. Geophys Res., 90, 7872-7880, 1985.

Goodsite, M., Plane, J., and Skov, H.: A theoretical study of the oxidation of $\mathrm{Hg} 0$ to $\mathrm{HgBr} 2$ in the troposphere, Environ. Sci. Technol., 38, 1772-1776, doi:10.1021/es034680s, 2004.

Granier, C., Guenther, A., Lamarque, J., Mieville, A., Muller, J., Olivier, J., Orlando, J., Peters, J., Petron, G., Tyndall, G., and Wallens, S.: POET, a database of surface emissions of ozone precursors, tech report, available at: http://www.aero.jussieu.fr/ projet/ACCENT/POET.php (last access: 1 March 2010), 2005.

Graydon, J. A., St. Louis, V. L., Lindberg, S. E., Hintelmann, H., and Krabbenhoft, D. P.: Investigation of mercury exchange between forest canopy vegetation and the atmosphere using a new dynamic chamber, Environ. Sci. Technol., 40, 4680-4688, 2006.

Guenther, A., Karl, T., Harley, P., Wiedinmyer, C., Palmer, P. I., and Geron, C.: Estimates of global terrestrial isoprene emissions using MEGAN (Model of Emissions of Gases and Aerosols from Nature), Atmos. Chem. Phys., 6, 3181-3210, doi:10.5194/acp-63181-2006, 2006.

Gustin, M., Biester, H., and Kim, C.: Investigation of the lightenhanced emission of mercury from naturally enriched substrates, Atmos. Environ., 36, 3241-3254, 2002.

Hall, B.: The gas phase oxidation of elemental mercury by ozone, Water Air Soil Pollut., 80, 301-315, 1995.

Han, Y., Holsen, T., Lai, S., Hopke, P., Yi, S., Liu, W., Pagano, J., Falanga, L., Milligan, M., and Andolina, C.: Atmospheric gaseous mercury concentrations in New York State: relationships with meteorological data and other pollutants, Atmos. Environ., 38, 6431-6446, 2004.

Heald, C., Henze, D., Horowitz, L., Feddema, J., Lamarque, J.F., Guenther, A., Hess, P., Vitt, F., Seinfeld, J., Goldstein, A., and Fung, I.: Predicted change in global secondary organic aerosol concentrations in response to future climate, emissions, and land use change, J. Geophys. Res., 113, D05211, doi:10.1029/2007JD009092, 2008

Hedgecock, I. M., Pirrone, N., Trunfio, G. A., and Sprovieri, F.: Integrated mercury cycling, transport, and air-water exchange (MECAWEx) model, J. Geophys. Res., 111, D20302, doi:10.1029/2006JD007117, 2006

Hintelmann, H., Harris, R., Heyes, A., Hurley, J. P., Kelly, C. A., Krabbenhoft, D. P., Lindberg, S., Rudd, J. W. M., Scott, K. J., and St. Louis, V. L.: Reactivity and mobility of new and old mercury deposition in a Boreal forest ecosystem during the first year of the METAALICUS study, Environ. Sci. Technol., 36, 5034-5040, 2002.

Holmes, C., Jacob, D., and Yang, X.: Global lifetime of elemental mercury against oxidation by atomic bromine in the free troposphere, Geophys. Res. Lett., 33, L20808, doi:10.1029/2006GL027176, 2006

Holmes, C. D., Jacob, D. J., Corbitt, E. S., Mao, J., Yang, X., Talbot, R., and Slemr, F.: Global atmospheric model for mercury including oxidation by bromine atoms, Atmos. Chem. Phys., 10, 12037-12057, doi:10.5194/acp-10-12037-2010, 2010.

Horowitz, L., Walters, S., Mauzerall, D., Emmons, L., Rasch, P., Granier, C., Tie, X., Lamarque, J.-F., Schultz, M., and Tyndall, G.: A global simulation of tropospheric ozone and related tracers: 
Description and evaluation of MOZART, version 2, J. Geophys. Res., 108, 4784, doi:10.1029/2002JD002853, 2003.

Hudman, R. C.: Ozone production in transpacific Asian pollution plumes and implications for ozone air quality in California, J. Geophys. Res., 109, D23S10, doi:10.1029/2004JD004974, 2004.

Hynes, A., Donohoue, D., Goodsite, M., Hedgecock, I., Pirrone, N., and Mason, R.: Our current understanding of major chemical and physical processes affecting mercury dynamics in the atmosphere and at air-water/terrestrial interfaces, in: Mercury Fate and Transport in the Global Atmosphere, edited by: Pirrone, N. and Mason, R. P., chap. 14, Springer, 322-344, 2009.

Jacob, D. J., Logan, J. A., and Murti, P. P.: Effect of rising Asian emissions on surface ozone in the United States, Geophys. Res. Lett., 26, 2175-2178, doi:10.1029/1999GL900450, 1999.

Jaeglé, L., Jaffe, D. A., Price, H. U., Weiss-Penzias, P., Palmer, P. I., Evans, M. J., Jacob, D. J., and Bey, I.: Sources and budgets for $\mathrm{CO}$ and $\mathrm{O}_{3}$ in the northeastern Pacific during the spring of 2001: Results from the PHOBEA-II Experiment, J. Geophys. Res., 108, 8802, doi:10.1029/2002JD003121, 2003.

Kanamitsu, M., Ebisuzaki, W., Woollen, J., Yang, S.-K., Hnilo, J., Fiorino, M., and Potter, G.: The NCEP-DOE AMIP-II reanalysis (R-2), B. Am. Meteorol. Soc., 83, 1631-1643, 2002.

Kellerhals, M., Beauchamp, S., Belzer, W., Blanchard, P., Froude, F., Harvey, B., McDonald, K., Pilote, M., Poissant, L., Puckett, K., Schroeder, B., Steffen, A., and Tordon, R.: Temporal and spatial variability of total gaseous mercury in Canada: results from the Canadian Atmospheric Mercury Measurement Network (CAMNet), Atmos. Environ., 37, 1003-1011, 2003.

Kim, S., Han, Y., Holsen, T., and Yi, S.: Characteristic of atmospheric speciated mercury concentrations (TGM, $\mathrm{Hg}$ (II), and $\mathrm{Hg}(\mathrm{p}))$ in Seoul, Korea, Atmos. Environ., 43, 3267-3274, 2009.

Kock, H., Bieber, E., Ebinghaus, S., and Thees, B.: Comparison of long-term trends and seasonal variation of atmospheric mercury concentrations at two European coastal monitoring stations Mace Head, Ireland and Zingst, Germany, Atmos. Environ., 39, 75497556, 2005 .

Lalonde, J. D., Kraepiel, A. M. L., and Morel, F. M. M.: Photooxidation of $\mathrm{Hg}(0)$ in artificial and natural waters, Environ. Sci. Technol., 35, 1367-1372, 2001.

Lamarque, J.-F., Hess, P., Emmons, L., Buja, L., Washington, W., and Granier, C.: Tropospheric ozone evolution between 1890 and 1990, J. Geophys. Res., 110, D08304, doi:10.1029/2004JD005537, 2005.

Lamarque, J.-F., Kinnison, D., Hess, P., and Vitt, F.: Simulated lower stratospheric trends between 1970 and 2005: identifying the role of climate and composition changes, J. Geophys. Res.Atmos, 113, D12301, doi:10.1029/2007JD009277, 2008.

Lamarque, J.-F., Emmons, L. K., Hess, P. G., Kinnison, D. E., Tilmes, S., Vitt, F., Heald, C. L., Holland, E. A., Lauritzen, P. H., Neu, J., Orlando, J. J., Rasch, P. J., and Tyndall, G. K.: CAM-chem: description and evaluation of interactive atmospheric chemistry in the Community Earth System Model, Geosci. Model Dev., 5, 369-411, doi:10.5194/gmd-5-369-2012, 2012.

Lamborg, C., Rolfhus, K., Fitzgerald, W., and Kim, G.: The atmospheric cycling and air-sea exchange of mercury species in the South and equatorial Atlantic Ocean, Deep-Sea Res. Pt. II, 46, 957-977, 1999.
Lamborg, C., Fitzgerald, W., Damman, W., Benoit, J., Balcom, P., and Engstrom, D.: Modern and historic atmospheric mercury fluxes in both hemispheres: global and regional mercury cycling implications, Global Biogeochem. Cy., 16, 1104 , doi:10.1029/2001GB001847, 2002a.

Lamborg, C. H., Fitzgerald, W. F., O’Donnell, J., and Torgersen, T.: A non-steady-state compartmental model of global-scale mercury biogeochemistry with interhemispheric gradients, Geochim. Cosmochim. Acta, 66, 1105-1118, 2002b.

Laurier, F., Mason, R., Whalin, L., and Kato, S.: Reactive gaseous mercury formation in the North Pacific Ocean's marine boundary layer: a potential role of halogen chemistry, J. Geophys. Res., 108, 4529, doi:10.1029/2003JD003625, 2003.

Leaner, J. J., Dabrowski, J. M., Mason, R. P., Resane, T., Richardson, M., Ginster, M., Gericke, G., Petersen, C. R., Masekoameng, E., Ashton, P. J., and Murray, K.: Mercury emissions from point sources in South Africa, in: Mercury Fate and Transport in the Global Atmosphere, edited by: Pirrone, N. and Mason, R., Springer Verlag, Dordrecht, 113-130, 2009.

Lei, H.,Wuebbles, D. J., and Liang, X.-Z.: Projected risk of high ozone episodes in 2050, Atmos. Environ., 59, 567-577. doi:10.1016/j.atmosenv.2012.05.051, 2012.

Lei, H., Wuebbles, D. J., Liang, X.-Z., and Olsen, S.: Domestic versus international contributions on 2050 ozone air quality: how much is convertible by regional control?, Atmos. Environ., 68, 315-325, doi:10.1016/j.atmosenv.2012.12.002, 2013.

Liang, X.-Z., Li, L., Kunkel, K., Ting, M., and Wang, J.: Regional climate model simulation of US precipitation during 1982-2002, Part 1: Annual cycle, J. Climate, 17, 3510-3528, 2004.

Lin, C.-J. and Pehkonen, S.: Aqueous free radical chemistry of mercury in the presence of iron oxides and ambient aerosol, Atmos. Environ., 31, 4125-4137, 1997.

Lin, C.-J. and Pehkonen, S.: Oxidation of elemental mercury by aqueous chlorine (HOCl/OCl-), J. Geophys. Res., 103, $28093-$ 28201, 1998.

Lin, C.-J. and Pehkonen, S.: The chemistry of atmospheric mercury: a review, Atmos. Environ., 33, 2067-2079, 1999.

Lin, C.-J., Pongprueksa, P., Lindberg, S., Pehkonen, S., Byun, D., and Jang, C.: Scientific uncertainties in atmospheric mercury models, Part I: Model science evaluation, Atmos. Environ., 40, 2911-2928, 2006.

Lin, C.-J., Pongprueksa, P., Bullock, O. R., Lindberg, S., Pehkonen, S., Jang, C., Braverman, T., and Ho, C. T.: Scientific uncertainties in atmospheric mercury models, Part II: Sensitivity analysis in the CONUS domain, Atmos. Environ., 41, 6544-6560, 2007.

Lin, X. and Tao, Y.: A numerical modelling study on regional mercury budget for eastern North America, Atmos. Chem. Phys., 3, 535-548, doi:10.5194/acp-3-535-2003, 2003.

Lindberg, S. E. and Vermette, S. J.: Workshop on sampling mercury in precipitation for the National Atmospheric Deposition Program, Atmos. Environ., 29, 1219-1220, 1995.

Lindberg, S., Kim, K., Meyers, T., and Owens, J.: Micrometeorological gradient approach for quantifying air-surface exchange of mercury vapor: tests over contaminated soils, Environ. Sci. Technol., 29, 126-135, 1995.

Lindqvist, O.: Mercury in the Swedish environment: recent research on causes, consequences and corrective methods, Water Air Soil Pollut., 55, xi-261, doi:10.1007/BF00542429, 1991. 
Liss, P. and Slater, P.: Flux of gases across the airsea interface, Nature, 247, 181-184, 1974.

Liu, B., Keeler, G., Dvonch, J., Barres, J., Lynam, M., Marsik, F., and Morgan, J.: Temporal variability of mercury speciation in urban air, Atmos. Environ., 41, 1911-1923, 2007.

Liu, H., Jacob, D., Bey, I., and Yantosca, R.: Constraints from Pb210 and Be-7 on wet deposition and transport in a global threedimensional chemical tracer model driven by assimilated meteorological fields, J. Geophys. Res., 106, 12109-12128, 2001.

Lyman, S. N. and Jaffe, D. A.: Formation and fate of oxidized mercury in the upper troposphere and lower stratosphere, Nature Geosci., 5, 114-117, doi:10.1038/NGEO1353, 2011.

Pacyna, E. G., Pacyna, J. M., Steenhuisen, F., and Wilson, S.: Global anthropogenic mercury emission inventory for 2000, Atmos. Environ., 40, 4048-4063, 2006.

Mao, J., Jacob, D. J., Evans, M. J., Olson, J. R., Ren, X., Brune, W. H., Clair, J. M. St., Crounse, J. D., Spencer, K. M., Beaver, M. R., Wennberg, P. O., Cubison, M. J., Jimenez, J. L., Fried, A., Weibring, P., Walega, J. G., Hall, S. R., Weinheimer, A. J., Cohen, R. C., Chen, G., Crawford, J. H., McNaughton, C., Clarke, A. D., Jaeglé, L., Fisher, J. A., Yantosca, R. M., Le Sager, P., and Carouge, C.: Chemistry of hydrogen oxide radicals $\left(\mathrm{HO}_{\mathrm{x}}\right)$ in the Arctic troposphere in spring, Atmos. Chem. Phys., 10, 58235838, doi:10.5194/acp-10-5823-2010, 2010.

Masekoameng, K. E., Leaner, J., and Dabrowski, J.: Trends in anthropogenic mercury emissions estimated for South Africa during 2000-2006, Atmos. Environ., 44, 3007-3014, 2010.

Mason, R. P.: Mercury emissions from natural processes and their importance in the global mercury cycle, Springer, New York, USA, chap. 7, 173-191, 2009.

Mason, R. and Sheu, G.: Role of the ocean in the global mercury cycle, Global Biogeochem. Cy., 16, 1093, doi:10.1029/2001GB001440, 2002.

Munthe, J.: Aqueous oxidation of elemental $\mathrm{Hg}$ by O3, Atmos. Environ., 26, 1461-1468, 1992.

Murazaki, K. and Hess, P.: How does climate change contribute to surface ozone change over the United States?, J. Geophys. Res., 111, D05301, doi:10.1029/2005JD005873, 2006.

National Atmospheric Deposition Program (NADP): Annual data summaries, available at: http://nadp.sws.uiuc.edu/lib/ dataReports.aspx (last access: 1 March 2010), 2008.

Nelson, P. F.: Atmospheric emissions of mercury from Australian point sources, Atmos. Environ., 41, 1717-1724, doi:10.1016/j.atmosenv.2006.10.029, 2007.

Nriagu, J. and Becker, C.: Volcanic emissions of mercury to the atmosphere: global and regional inventories, Sci. Total Environ., 304, 3-12, 2003.

Olivier, J., Berdowski, J., Peters, J., Bakker, J., Visschedijk, A., and Bloos, J.: Applications of EDGAR, Including a description of EDGAR V3.0: reference database with trend data for 19701995, report no. 773301 001/NRP report 410200 051, ISBN: 905851-077-8, RIVM, Bilthoven, 2001.

Olivier, J., Peters, J., Granier, C., Petron, G., Muller, J- F., and Wallens, S.: Present and future surface emissions of atmospheric compounds, POET report no 2, EU project EVK2-1999-00011, 2003.

Pacyna, E., Pacyna, J., Steenhuisen, F., and Wilson, S.: Global anthropogenic mercury emission inventory for 2000, Atmos. Environ., 40, 4048-4063, 2005.
Pal, B. and Ariya, P.: Studies of ozone initiated re actions of gaseous mercury: kinetics, product studies and atmospheric implications, Phys. Chem. Chem. Phys., 6, 572-579, doi:10.1039/b311150d, 2004.

Parrella, J. P., Jacob, D. J., Liang, Q., Zhang, Y., Mickley, L. J., Miller, B., Evans, M. J., Yang, X., Pyle, J. A., Theys, N., and Van Roozendael, M.: Tropospheric bromine chemistry: implications for present and pre-industrial ozone and mercury, Atmos. Chem. Phys., 12, 6723-6740, doi:10.5194/acp-12-6723-2012, 2012.

Parrish, D. D., Kondo, Y., Cooper, O. R., Brock, C. A., Jaffe, D. A., Trainer, M., Ogawa, T., Hübler, G., and Fehsenfeld, F. C.: Intercontinental Transport and Chemical Transformation 2002 (ITCT 2K2) and Pacific Exploration of Asian Continental Emission (PEACE) experiments: An overview of the 2002 winter and spring intensives, J. Geophys. Res., 109, D23S01, doi:10.1029/2004JD004980, 2004.

Pehkonen, S. and Lin, C.: Aqueous photochemistry of mercury withorganic acids, J. Air Waste Ma., 48, 144-150, 1998.

Pfister, G., Emmons, L., Hess, P., and Lamarque, J.-F.: Contribution of isoprene to chemical budgets: a model tracer study with the NCAR CTM MOZART-4, J. Geophys. Res.-Atmos, 113, D05308, doi:10.1029/2007JD008948, 2008

Pirrone, N. and Keating, T.: Hemispheric Transport of Air Pollution 2010. Part B: Mercury, 97-144, Air Pollution Studies No. 16, United Nations, 2010.

Pirrone, N., Cinnirella, S., Feng, X., Finkelman, R. B., Friedli, H. R., Leaner, J., Mason, R., Mukherjee, A. B., Stracher, G. B., Streets, D. G., and Telmer, K.: Global mercury emissions to the atmosphere from anthropogenic and natural sources, Atmos. Chem. Phys., 10, 5951-5964, doi:10.5194/acp-10-59512010, 2010.

Pleijel, K. and Munthe, J.: Modeling the atmospheric Mercury cycle - Chemistry in fog droplets, Atmos. Environ., 29, 1441-1457, 1995.

Poissant, L. and Casimir, A.: Water-air and soil-air exchange rate of total gaseous mercury measured at background sites, Atmos. Environ., 32, 883-893, 1998.

Pyle, D. and Mather, T.: The importance of volcanic emissions for the global atmospheric mercury cycle, Atmos. Environ., 37, 5115-5124, 2003.

Ren X., Brooks, S., Luke, W. T., Kelley, P., Cohen, M., Artz, R., Hynes, A., Landing, W., and Martos, B.: Airborne vertical profiling of mercury speciation in Tennessee, USA, in preparation, 2013.

Rutter, A. P. and Schauer, J. J.: The effect of temperature on the gasparticle partitioning of reactive mercury in atmospheric aerosols, Atmos. Environ., 41, 8647-8657, 2007.

Rutter, A. P., Shakya, K. M., Lehr, R., Schauer, J. J., and Griffin, R. J.: Oxidation of gaseous elemental mercury in the presence of secondary organic aerosols, Atmos. Environ., 59, 86-92, 2012.

Saiz-Lopez, A., Lamarque, J.-F., Kinnison, D. E., Tilmes, S., Ordóñez, C., Orlando, J. J., Conley, A. J., Plane, J. M. C., Mahajan, A. S., Sousa Santos, G., Atlas, E. L., Blake, D. R., Sander, S. P., Schauffler, S., Thompson, A. M., and Brasseur, G.: Estimating the climate significance of halogen-driven ozone loss in the tropical marine troposphere, Atmos. Chem. Phys., 12, 3939-3949, doi:10.5194/acp-12-3939-2012, 2012. 
Sakata, M. and Marumoto, K.: Formation of atmospheric particulate mercury in the Tokyo metropolitan area, Atmos. Environ., 36, 239-246, 2002.

Schroeder, W. and Munthe, J.: Atmospheric mercury - An overview, Atmos. Environ., 32, 809-822, 1998.

Seigneur, S., Karamchandani, P., Lohman, K., and Vijayaraghavan, K.: Multiscale modeling of the atmospheric fate and transport of mercury, J. Geophys. Res., 106, 27795-27809, 2001.

Seigneur, S., Vijayaraghavan, K., Lohman, K., Karamchandani, P., and Scott, C.: Global source attribution for mercury deposition in the United States, Environ. Sci. Technol., 38, 555-569, 2004.

Selin, N., Jacob, D., Park, R., Yantosca, R., Strode, S., Jaeglé, L., and Jaffe, D.: Chemical cycling and deposition of atmospheric mercury: global constraints from observations, J. Geophys. Res., 112, 1-14, doi:10.1029/2006JD007450, 2007.

Selin, N., Jacob, D., Yantosca, R., Strode, S., Jaeglé, L., and Sunderland, E.: Global 3-D land-ocean-atmosphere model for mercury: present-day versus preindustrial cycles and anthropogenic enrichment factors for deposition, Global Biogeochem. Cy., 22, 1-13, doi:10.1029/2007GB003040, 2008.

Shia, R.-L., Seigneur, C., Pai, P., Ko, M., and Sze, N.: Global simulation of atmospheric mercury concentrations and deposition fluxes, J. Geophys. Res., 104, 23747-23760, 1999.

Singh, H. B., Brune, W. H., Crawford, J. H., Flocke, F., and Jacob, D. J.: Chemistry and transport of pollution over the Gulf of Mexico and the Pacific: spring 2006 INTEX-B campaign overview and first results, Atmos. Chem. Phys., 9, 2301-2318, doi:10.5194/acp-9-2301-2009, 2009.

Slemr, F., Brunke, E.-G., Labuschagne, C., and Ebinghaus, R.: Total gaseous mercury concentrations at the Cape Point GAW station and their seasonality, Geophys. Res. Lett., 35, L11807, doi:10.1029/2008GL033741, 2008.

Smith-Downey, N., Sunderland, E., and Jacob, D.: Anthropogenic impacts on global storage and emissions of mercury from terrestrial soils: insights from a new global model, J. Geophys. Res., 115, G03008, doi:10.1029/2009JG001124, 2010.

Soerensen, A., Skov, H., Jacob, D., Soerensen, B., and Johnson, M.: Global concentrations of gaseous elemental mercury and reactive gaseous mercury in the marine boundary layer, Environ. Sci. Technol., 44, 7425-7430, 2010.

Sommar, J., Garfeldt, K., Stromberg, D., and Feng, X.: A kinetic study of the gas-phase reaction between the hydroxyl radical and atomic mercury, Atmos. Environ., 35, 3049-3054, 2001.

Sprovieri, F., Pirrone, N., Hedgecock, I. M., Landis, M. S., and Stevens, R. K.: Intensive atmospheric mercury measurements at Terra Nova Bay in Antarctica during November and December 2000, J. Geophys. Res., 107, 4722-4729, 2002.

Streets, D., Hao, J., Wu, Y., Jiang, J., Chan, M., Tian, H., and Feng, X.: Anthropogenic mercury emissions in China, Atmos. Environ., 39, 7789-7806, 2005.

Streets, D., Zhang, Q., and Wu, Y.: Projections of global mercury emissions in 2050, Environ. Sci. Technol., 43, 2983-2988, doi:10.1021/es802474j, 2009.

Subir, M., Ariya, P. A., and Dastoor, A. P.: A Review of the Sources of Uncertainties in Atmospheric Mercury Modeling II. Mercury surface and heterogeneous chemistry - A missing link, Atmos. Environ., 46, 1-10, 2011.

Swartzendruber, P. C., Chand, D., Jaffe, D. A., Smith, J., Reidmiller, D., Gratz, L., Keeler, J., Strode, S., Jaegle, L., and
Talbot, R.: Vertical distribution of mercury, CO, ozone, and aerosol scattering coefficient in the Pacific Northwest during the spring 2006 INTEX-B campaign, J. Geophys. Res., 113, D10305, doi:10.1029/2007JD009579, 2008.

Talbot, R., Mao, H., Scheuer, E., Dibb, J., Avery, M., Browell, E., Sachse, G., Vay, S., Blake, D., Huey, G., and Fuelberg, H.: Factors influencing the large-scale distribution of $\mathrm{Hg}^{\circ}$ in the Mexico City area and over the North Pacific, Atmos. Chem. Phys., 8, 2103-2114, doi:10.5194/acp-8-2103-2008, 2008.

Temme, C., Einax, J., Ebinghaus, R., and Schroeder, W.: Measurements of atmospheric mercury species at a coastal site in the Antarctic and over the South Atlantic Ocean during polar summer, Environ. Sci. Technol., 37, 22-31, 2003.

Temme, C., Blanchard, P., Steffen, A., Banic, C., Beauchamp, S., Poissant, L., Tordon, R., and Wiens, B.,: Trend, seasonal and multivariate analysis study of total gaseous mercury data from the Canadian atmospheric mercury measurement network (CAMNet), Atmos. Environ., 41, 5423-5441, 2007.

Tie, X., Brasseur, G., Emmons, L., Horowitz, L., and Kinnison, D.: Effects of aerosols on tropospheric oxidants: a global model study, J. Geophys. Res. 106, 22931-22964, 2001.

Tie, X., Madronich, S., Walters, S., Edwards, D., Ginoux, P., Mahowald, N., Zhang, R., Lou, C., and Brasseur, G.: Assessment of the global impact of aerosols on tropospheric oxidants, J. Geophys. Res., 110, D03204, doi:10.1029/2004JD005359, 2005.

Talbot, R., Mao, H., Scheuer, E., Dibb, J., Avery, M., Browell, E., Sachse, G., Vay, S., Blake, D., Huey, G., and Fuelberg, H.: Factors influencing the large-scale distribution of $\mathrm{Hg}^{\circ}$ in the Mexico City area and over the North Pacific, Atmos. Chem. Phys., 8, 2103-2114, doi:10.5194/acp-8-2103-2008, 2008.

USEPA: Mercury Study Report to Congress, Fate and Transport of Mercury in the Environment, vol. III, EPA-452/R-97-005, US Environmental Protection Agency, US Government Printing Office, Washington, DC, 1997.

van der Werf, G. R., Randerson, J. T., Giglio, L., Collatz, G. J., Kasibhatla, P. S., and Arellano Jr., A. F.: Interannual variability in global biomass burning emissions from 1997 to 2004, Atmos. Chem. Phys., 6, 3423-3441, doi:10.5194/acp-6-3423-2006, 2006.

Van Loon, L., Mader, E., and Scott, S.: Reduction of the aqueous mercuric ion by sulfite: UV spectrum of $\mathrm{HgSO} 3$ and its intramolecular redox reaction. J. Phys. Chem., 104, 1621-1626, 2000.

Wanninkhof, R.: Relationship between wind speed and gas exchange over the ocean, J. Geophys. Res., 97, 7373-7382, 1992.

Wang, Y., Jacob, D., and Logan, J.: Global simulation of tropospheric O3-NOx-hydrocarbon chemistry: 1. Model formulation, J. Geophys. Res., 103, 10713-10726, 1998.

Wang, Z. and Pehkonen, S. O.: Oxidation of elemental mercury by aqueous bromine: atmospheric implications, Atmos. Environ., 38, 3675-3688, 2004.

Wang, Z., Zhang, X., Chen, Z., and Zhang, Y.: Mercury concentrations in size-fractionated airborne particles at urban and suburban sites in Beijing, China, Atmos. Environ., 40, 2194-2201, 2006.

Wamsley, J. and Wesley, M.: Modification of coded parameterizations of surface resistances to gaseous dry deposition, Atmos. Environ., 30, 1181-1188, 1996. 
Wängberg, I., Schmolke, S., Schager, P., Munthe, J., Ebinghaus, R., and Iverfeldt, A.: Estimates of air-sea exchange of mercury in the Baltic Sea, Atmos. Environ., 35, 5477-5484, 2001.

Weiss-Penzias, P., Jaffe, D., McClintick, A., Prestbo, E., and Landis, M.: Gaseous elemental mercury in the marine boundary layer: evidence for rapid removal in anthropogenic pollution, Environ. Sci. Technol., 37, 3755-3763, 2003.

Wesley, M.: Parameterizations of surface resistances to gaseous dry deposition in regional scale numerical models, Atmos. Environ., 23, 1293-1304, 1989.

Wesley, M. and Hicks, B.: A review of the current status of knowledge on dry deposition, Atmos. Environ., 34, 2261-2282, 2000.

Wilkening, K. E., Barrie, L. A., and Engle, M.: Trans-Pacific air pollution, Science, 290, 65-67, doi:10.1126/science.290.5489.65, 2000.

Witt, M., Mather, T., Pyle, D., Aiuppa, A., Bagnato, E., and Tsanev, V. I.: Mercury and halogen emissions from Masaya and Telica volcanoes, Nicaragua, J. Geophys. Res.-Sol. Ea., 113, B06203, doi:10.1029/2007JB005401, 2008.

Witt, M., Mather, T., Baker, A., De Hoog, J., and Pyle, D.: Atmospheric trace metals over the south-west Indian Ocean: total gaseous mercury, aerosol trace metal concentrations and lead isotope ratios, Mar. Chem., 121, 2-16, doi:10.1016/j.marchem.2010.02.005, 2010.
Wuebbles, D., Lei, H., and Lin, J.-T.: Intercontinental transport of aerosols and photochemical oxidants from Asia and its consequences, Environ. Pollut., 150, 65-84, 2007.

Xiao, X., Yang, X., Miller, D., Helble, J., and Carley, R.: A regional scale modeling study of atmospheric transport and transformation of mercury, II. Simulation results for the northeast United States, Atmos. Environ., 34, 4945-4955, 1994.

Yang, Y., Chen, H., and Wang, D.: Spatial and temporal distribution of gaseous elemental mercury in Chongqing, China, Environ. Monit. Assess., 156, 479-489, 2009.

Yienger, J. J., Galanter, M., Holloway, T. A., Phadinx, M. J., Guttikunda, S. K., Carmichael, G. R., Moxim, W. J., and Levy 1l, H.: The episodic nature of air pollution transport from Asia to North America, J. Geophys. Res., 105, 931-945, 2000.

Zhang, H., Lindberg, S., Marsik, F., and Keeler, G.: Mercury air/surface exchange kinetics of background soils of the Tahquamenon River watershed in the Michigan Upper Peninsula, Water Air Soil Pollut., 126, 151-169, 2001. 